\title{
Direct and legacy effects of plant-traits control litter decomposition in a deciduous oak forest in Mexico
}

\author{
Bruno Chávez-Vergara $^{1}{ }^{\text {， Agustín Merino }}{ }^{2}$, Antonio González-Rodríguez ${ }^{3}$, Ken Oyama ${ }^{4}$, Felipe García-Oliva \\ Corresp. 5 \\ 1 Instituto de Geología, Universidad Nacional Autónoma de México, Ciudad de Mexico, Mexico \\ 2 Escuela Politécnica Superior, Universidad de Santiago de Compostela, Lugo, Galicia, Spain \\ 3 Instituto de Investigaciones en Ecosistemas y Sustentabilidad, UNAM, Morelia, Michoacán, Mexico \\ 4 Escuela Nacional de Estudios Superiores Unidad Morelia, Universidad Nacional Autónoma de México, Morelia, Michoacán, Mexico \\ 5 Instituto de Investigaciones en Ecosistemas y Sustentabilidad, Universidad Nacional Autónoma de México, Morelia, Michoacán, Mexico \\ Corresponding Author: Felipe García-Oliva \\ Email address: fgarcia@cieco.unam.mx
}

Background. Litter decomposition is a key process in the functioning of forest ecosystems, because it strongly controls nutrient recycling and soil fertility maintenance. The interaction between the litter chemical composition and the metabolism of the soil microbial community has been described as the main factor of the decomposition process based on three hypotheses: substrate-matrix interaction (SMI), functional breadth (FB) and home-field advantage (HFA). The objective of the present study was to evaluate the effect of leaf litter quality (as a direct plant effect, SMI hypothesis), the metabolic capacity of the microbial community (as a legacy effect, FB hypothesis), and the coupling between the litter quality and microbial activity (HFA hypothesis) on the litter decomposition of two contiguous deciduous oak species at a local scale.

Methods. To accomplish this objective, we performed a litterbag experiment in the field for 270 days to evaluate mass loss, leaf litter quality and microbial activity in a complete factorial design for litter quality and species site.

Results. The litter of Quercus deserticola had higher rate of decomposition independently of the site, while the site of $Q$. castanea promoted a higher rate of decomposition independently of the litter quality, explained by the specialization of the soil microbial community in the use of recalcitrant organic compounds. The Home-Field Advantage index was reduced with the decomposition date ( $22 \%$ and $4 \%$ for 30 and 270 days, respectively).

Discussion. We observed that the importance of the coupling of litter quality and microbial activity depends on decomposition stage. At the early decomposition stage, the home-advantage hypothesis explained the mass loss of litter; however, in the advanced decomposition stage, the litter quality and the 
metabolic capacity of the microbial community can be the key drivers. 
1 Direct and legacy effects of plant-traits control litter decomposition in a deciduous oak

2 forest in Mexico

3 Bruno Chávez-Vergara ${ }^{1,5}$, Agustín Merino $^{2}$, Antonio González-Rodríguez ${ }^{3}$, Ken Oyama ${ }^{4}$, Felipe

4 García-Oliva ${ }^{3 *}$

51 Departamento de Edafología, Instituto de Geología, Universidad Nacional Autónoma de

6 México, 04510 Ciudad de México, (México).

72 Department of Soil Science and Agricultural Chemistry, Escuela Politécnica Superior,

8 Universidad de Santiago de Compostela, 27002 Lugo (Spain).

$9{ }^{3}$ Instituto de Investigaciones en Ecosistemas y Sustentabilidad, Universidad Nacional Autónoma 10 de México, 58090 Morelia (México).

$11{ }^{4}$ Escuela Nacional de Estudios Superiores Campus Morelia, Universidad Nacional Autónoma de

12 México, 58090 Morelia (México).

135 Laboratorio Nacional de Mineralogía y Geoquímica (LANGEM), 04510 Ciudad de México 14 (México)

15 *Corresponding author. Felipe García-Oliva ${ }^{3}$. e-mail: fgarcia@cieco.unam.mx 


\section{Abstract}

Background. Litter decomposition is a key process in the functioning of forest ecosystems, because it strongly controls nutrient recycling and soil fertility maintenance. The interaction between the litter chemical composition and the metabolism of the soil microbial community has been described as the main factor of the decomposition process based on three hypotheses: substrate-matrix interaction (SMI), functional breadth (FB) and home-field advantage (HFA). The objective of the present study was to evaluate the effect of leaf litter quality (as a direct plant effect, SMI hypothesis), the metabolic capacity of the microbial community (as a legacy effect, FB hypothesis), and the coupling between the litter quality and microbial activity (HFA hypothesis) on the litter decomposition of two contiguous deciduous oak species at a local scale.

Methods. To accomplish this objective, we performed a litterbag experiment in the field for 270 days to evaluate mass loss, leaf litter quality and microbial activity in a complete factorial design for litter quality and species site.

Results. The litter of Quercus deserticola had higher rate of decomposition independently of the site, while the site of $Q$. castanea promoted a higher rate of decomposition independently of the litter quality, explained by the specialization of the soil microbial community in the use of recalcitrant organic compounds. The Home-Field Advantage index was reduced with the decomposition date ( $22 \%$ and $4 \%$ for 30 and 270 days, respectively)

Discussion. We observed that the importance of the coupling of litter quality and microbial activity depends on decomposition stage. At the early decomposition stage, the home-advantage hypothesis explained the mass loss of litter; however, in the advanced decomposition stage, the litter quality and the metabolic capacity of the microbial community can be the key drivers. 
40 Key words: Litter decomposition, Quercus, Differential Scaning Calorimetry, 13C NMR,

41 Enzymatic activity

42

43

44

\section{Introduction}

Litter decomposition is a key process in the functioning of forest ecosystems, because it strongly controls nutrient recycling and soil fertility maintenance (Austin et al., 2014). At the local scale, the decomposition rate is strongly affected by litter traits and microbial activity (Freschet et al., 2012). The litter traits that promote the decomposition are related with physical features as the rate of water uptake in litter (Makkonen et al., 2013). Additionally, some chemical characteristics of litter can promote its decomposition such as: a) a low C: N ratio (Ågren et al., 2013; Aponte et al., 2013; Bononomi et al., 2013; Osono et al., 2013), b) a high concentration of soluble organic forms (Berg, 2014), and c) a low proportion of lignin or phenolic compounds (Almendros et al., 2000; Prescott 2010; Ono et al., 2011), as well as changes in the proportions of lignin subunits (Chávez-Vergara et al., 2014; Talbot et al., 2012). The study of the effects of leaf litter traits on decomposition has been reported before by several authors (i.e., Grime and Anderson, 1986; Bass et al., 1989, Grime et al., 1996); and more recently, these traits as called "after life" traits, because they are products of the metabolism of living plant species, and they can regulate ecological process, as litter decomposition (Genung et al., 2013).

The decomposition rate of organic compounds is also associated with the composition of the soil microbial community and its metabolism (Austin et al., 2014; Freschet et al., 2012). For example, the presence of actinomycetes (Snajdr et al., 2011) and basidiomycetes species (Osono \& Takeda 2002; Snajdr et al., 2011) favors the degradation of recalcitrant compounds (i.e. lignin, 
61 polyphenols, aliphatics), because these microbial taxa are capable of producing exoenzymes

62 which can cleave these organic molecules (Allison et al., 2014). Consequently, the inhibitory

63 effect on litter decomposition of a high proportion of recalcitrant molecules can be reduced by

64 the activity of specialized microbial species (Cleveland et al., 2004; Strickland et al., 2009;

65 Snajdr et al. 2011; Chávez-Vergara et al., 2016). Therefore, the metabolic capacity of the

66 microbial community can be considered as a "legacy" effect over litter decomposition (Wurst \&

67 Ohgushi, 2015). These authors defined legacy effect as "a specific case of long-term e $\square$ ects that

68 persist after the biotic interaction that caused the e $\square$ ects ceases ". Recent studies have shown that

69 the interaction between the chemical composition of the plant residues and the metabolic capacity of the microbial community is the most important factor in the regulation of the litter decomposition rate (Austin et al., 2004; Ayres et al., 2009; Fanin et al., 2016; García-Palacios et al., 2016; Hicks Pries et al., 2017). This interaction involves the functional traits of plant species (i.e. chemical characteristics of plant residues) and the activity of the microbial community of the forest floor (i.e. production of exoenzymes) (Ayres et al., 2009; Austin et al., 2014; Pearse et al., 2014; Fanin et al., 2016). community of the forest floor has been described by the following hypotheses: A) home-field advantage (HFA), which states that the litter will be more easily decomposed by the microbial community in the same site where it was produced (Ayres et al., 2009, Austin et al., 2014); B) substrate-matrix interaction (SMI), in which exogenous litter can be decomposed at the same rate than endogenous litter if both have a similar chemical composition (Freschet et al., 2012) and, more recently, C) the functional breadth hypothesis (FB), according to which microbial communities that have been exposed to substrates with low chemical quality have developed 
84 mechanisms for the use of substrates with different chemical quality; in other words, are

85

86

87

88

89

90

91

92

93

94

95

96

97

functionally more diverse, and capable of using a wide-range of substrates (Fanin et al., 2016).

Therefore, the objective of the present study was to evaluate the effect of leaf litter quality (as a direct plant effect, SMI hypothesis), the metabolic capacity of the microbial community (as a legacy effect, FB hypothesis), and the coupling between leaf litter quality and microbial activity (HFA hypothesis), on the litter decomposition of two species of deciduous oaks, by using a controlled field experiment of litter decomposition.

In previous studies, we found that Quercus deserticola promoted higher nutrient availability than $Q$. castanea, because the former oak species produced leaf litter with higher chemical quality, therefore favoring microbial activity and litter chemical transformation (Chávez-Vergara et al., 2014; Chávez-Vergara et al., 2015). However, the microbial community in the litter of $Q$. castanea is dominated by microbial species specialized in the use of recalcitrant compounds, increasing the efficiency in the use of resources (Chávez-Vergara et al., 2016). Therefore, the main hypothesis of the present study is that the litter decomposition is regulated by the direct effect of the chemical composition of the plant residues, and the legacy effect on the specialization of the microbial community. Consequently, the site dominated by $Q$. castanea should have a higher potential of litter decomposition, but the $Q$. deserticola litterfall should be easier to decompose. Our study is the first report testing hypotheses on litter decomposition in species of the same genus, while most of the studies have been performed on taxonomically and functionally very distant plant species (i.e., Freschet et al., 2012; Pearse et al., 2014; Fanin et al., 2016).

To test our hypothesis, we performed a factorial field experiment of decomposition bags during 30 and 270 days with litterfall of $Q$. castanea (low quality), Q. deserticola (high quality) 
107 and a mix of both oak species litterfall (cumulative quality) in three sites based on the microbial 108 activity specialization: fast degradation of recalcitrant compounds (under $Q$. castanea), slow

109 degradation of recalcitrant compounds (under $Q$. deserticola) and an intermediate degradation,

110 which represents a wider spectrum of resources utilization for the microbial community (under

111 both Quercus species in interaction).

\section{Materials and methods}

2.1. Study site

115 This study was conducted within the Cuitzeo basin in El Remolino hill $\left(19^{\circ} 37^{\prime} 01^{\prime \prime} \mathrm{N}, 101^{\circ} 20^{\prime}\right.$

116 07"W; $11 \mathrm{~km}$ south of Morelia city, Michoacán, Mexico). The study site is an oak forest

117 fragment (>12 ha) with low disturbance (about 80 years without wood extraction for charcoal

118 production according to nearby inhabitants) and two dominant native oak species: Quercus

119 castanea Née (section Lobatae) and Q. deserticola Trel. (section Quercus). The characteristics of

120 this site and the species can be found in more detail in previous studies (Chavez-Vergara et al.

121 2014; Chávez-Vergara et al., 2015). Briefly, the predominant soil type is a chromic Luvisol

122 developed over Quaternary basalts. The climate in the area is temperate subhumid, with annual

123 mean temperature of $17.6^{\circ} \mathrm{C}$ and annual mean precipitation of $805 \mathrm{~mm}$ concentrated in the

124 summer months. In 2014, the annual rainfall was $850 \mathrm{~mm}$ and the average temperature was 16.6

$125{ }^{\circ} \mathrm{C}$. For the present study, three parallel plots of $30 \mathrm{X} 150 \mathrm{~m}$ were established perpendicular to

126 the main slope, where one of the studied species dominated in either of the two lateral plots; and

127 both species were mixed in the central plot. Therefore, three species conditions were present:

128 isolated Q. castanea (Qc), isolated Q. deserticola (Qd) and mixed Quercus species (Qx). 
129

130

131

132

133

134

135

136

137

138

139

140

141

142

143

144

145

146

147

148

149

150

\subsection{Litterfall collection}

A circular trap of $0.5 \mathrm{~m}^{2}$ was placed under each of five trees per species condition: isolated $Q$. castanea, mixed species and isolated $Q$. deserticola (15 traps in total) to collect litterfall every month from December 2012 to May 2014. The fresh litter samples were weighed, and an aliquot was dried to constant weight at $70{ }^{\circ} \mathrm{C}$ for $72 \mathrm{~h}$ to determine water content, which was then used to calculate the dry mass of each sample. The fresh aliquot was stored at $4{ }^{\circ} \mathrm{C}$ in darkness prior to laboratory analysis $(\mathrm{n}=5$ for each species). The monthly dried subsamples from the two sampling years were mixed for the litterbag experiment.

\section{3. Litterbags experiment}

\subsubsection{Field experiment}

Brown color polyester mesh $(1 \mathrm{~mm})$ bags $(10 \mathrm{X} 10 \mathrm{~cm})$ were used for the field decomposition experiment. The mesh size of $1 \mathrm{~mm}$ was chosen because it avoids losing small leaf litter debris but allows the activities of the aerobic microbial community and meso- and micro-fauna (Nguyen Tu et al., 2011), which play an important role in the initial fragmentation of litter (Gessner et al., 2010). These bags were filled with $11 \mathrm{~g}$ of oven-dried litterfall with the following arrangement: 30 bags with $Q$. castanea litterfall (QcL), 30 bags with $Q$. deserticola litterfall (QdL) and 30 bags with a mixture of both species litterfall (QxL) in the same proportion (5.5 $\mathrm{g}$ of $Q$. castanea and $5.5 \mathrm{~g}$ of $Q$. deserticola litterfall). In June 2014, two litterbags of each litterfall type (QcL, QdL and QxL) were randomly located above the litter and around the stem of each of the five-selected trees, distributed along the main slope, in each species condition plot (hereafter plots are referred as sites): Q. castanea site (QcS), Q. deserticola site (QdS) and the species mixture site (QxS). Therefore, the field design is a complete factorial 3 X 3 (site and litterfall 
151 conditions). One litterbag for each treatment per tree was harvested at 30 and 270 days after the

152 bags were placed ( 5 bags for each treatment). The comparison of the two dates allows us to

153 determine the decomposition effect on early and late decomposition stages, where the labile and

154 recalcitrant molecules proportion changes over-time. The means ( \pm standard deviation) of DBH

155 for trees in each condition was Qc: $52.9 \pm 11.7 \mathrm{~cm}, \mathrm{Qx}: 48.9 \pm 4.9 \mathrm{~cm}$ and Qd: $63.9 \pm 11.4 \mathrm{~cm}$.

156 In the collection dates, the content of each bag was carefully removed, fresh field weighed, and

157 subsequently divided into two subsamples. The first one was stored in hermetic bags in the dark

158 at $4{ }^{\circ} \mathrm{C}$ until laboratory analysis. The second subsample was dried to constant weight at $70{ }^{\circ} \mathrm{C}$

159 for 72 hours to calculate the water content. Then, the sample was milled in a ball mill at 350

160 RPM for 3 min and stored in sealed bags until chemical analysis.

161

162

163

164

165

166

167

168

169

170

171

172

\subsubsection{Remaining mass and decomposition rate}

Initial and remaining samples were combusted in a muffle furnace at $650{ }^{\circ} \mathrm{C}$ to determine inorganic particles to correct data on an ash-free basis. The litter decomposition rate was calculated using the simple exponential model: $\mathrm{MR}=\mathrm{Mi} \mathrm{e}^{-\mathrm{kt}}$; where $\mathrm{MR}$ is the percentage of the remaining mass at 270 days, $\mathrm{Mi}$ is the initial mass percentage, $\mathrm{k}$ is the decomposition rate and $\mathrm{t}$ is the decomposition time in field conditions (Olsen, 1963).

\subsection{Laboratory analysis}

The nutrients and enzymatic activity analyses were done at Instituto de Investigaciones en Ecosistemas y Sustentabilidad, UNAM, Mexico, while the ${ }^{13} \mathrm{C}$ Nuclear Magnetic Resonance and DSC analyzes were done at Universidad de Santiago de Compostela, Spain.

\subsection{1. ${ }^{13} \mathrm{C}$ Nuclear Magnetic Resonance $\left({ }^{13} \mathrm{C} \mathrm{NMR}\right)$ spectroscopy}


173 The ${ }^{13} \mathrm{C}$ Nuclear Magnetic Resonance spectroscopy is a non-destructive analysis that improves

174 the identification of the molecular composition from organic residues; it is useful tool for

175 determination of the molecular composition of litterfall and decomposed litter. To characterize

176 the chemical composition of litterfall and decomposed litter, the analysis of Cross Polarized

177 Magic-Angle $\operatorname{Spin}^{13} \mathrm{C}$ NMR in solid state was performed in samples previous to the field

178 experiment (initial) and in samples at the end of the field experiment (remaining). The ${ }^{13} \mathrm{C}$ NMR

179 data were obtained at $298 \mathrm{~K}$ in a Varian Inova-750 17.6 T (operated at $750 \mathrm{MHz}$ frequency

180 proton), under the conditions described in Chávez-Vergara et al. (2014). The spectrogram

181 obtained was processed with the program MestreNova V. 6 (Mestrelab Research Inc.).

For integration, the spectrogram was divided into four major regions representing

different chemical environments of ${ }^{13} \mathrm{C}$ nucleus according to position of relaxation signal in parts

per million of chemical shift (ppm): C Alkyl (0-45 ppm), O-alkyl C (45-110 ppm), aromatic C

(110-160 ppm) carbonyl and C (160-220 ppm). For more detailed analysis, spectra were divided

according to Leifeld \& Kögel-Knabner (2005) as: I) 10-45 ppm C alkyl: methyl groups,

methylene groups on rings and aromatic chains. II) 45-110 ppm C O-alkyl: methoxy groups and

C6 in some polysaccharides (45-60 ppm); C2-C5 hexoses C of some amino acids, aliphatic alcohols and fractions of lignin structure (60-90 ppm); Carbohydrate anomeric C, C2-C6 syringyl unit of lignin (90-110). III) 110-160 ppm aromatic C: and CC and CH carbon C2 guaiacil, C6 lignin (110-140 ppm, aryl C); COR aromatic or CNR (140-160 ppm, phenolic C) groups. IV) carboxyl 160-220 ppm C: carboxyl C, C carbonyl and C amide. aromaticity (Ai), hydrophobicity (HB: HI) and characterization of lignin relations based on 
196 subunits specific regions such as syringyl (S), guaiacyl (G) and p-hydroxyphenyl (H) as lignin

197 relations S:G, S:H and G:H (Almendros et al., 2000; Spaccini et al., 2006; Talbot et al., 2012;

198 Bonanomi et al., 2013; Chávez-Vergara et al., 2014).

199 2.4.2. Differential scanning calorimetry (DSC) and Thermogravimetry (TGA)

200 The Differential Scanning Calorimetry (DSC) and Thermogravimetry (TG) is a thermal analysis

201 suitable for determination of organic matter stability (Angehrn-Bettinazzi et al.,1998). This

202 method quantifies the energy release during different combustion temperatures of samples, like

203 the energy required for biological oxidation of organic molecules (Rovira et al., 2008).

204 Therefore, the thermograms can quantify the proportion of labile, recalcitrant and extra-

205 recalcitrant compounds in the organic samples (Barros et al., 2007). The characterization of

206 thermal properties of litterfall and decomposed litter was done by differential scanning

207 calorimetry and thermogravimetric analysis (DSC-TGA, Mettler-Toledo International Inc.). The

208 analysis was performed with $4 \mathrm{mg}$ of powdered oven-dried sample placed in an aluminum pan in

209 an atmosphere of dry air (flow rate, $50 \mathrm{ml} \mathrm{min}^{1}$ ) and the scan rate was $10{ }^{\circ} \mathrm{C} \mathrm{min}^{-1}$. The

210 temperature range used was 50 to $600{ }^{\circ} \mathrm{C}$. An indium sample (melting point: $156.6{ }^{\circ} \mathrm{C}$ ) was used

211 to calibrate the calorimeter. All samples were analyzed in triplicate.

212 The combustion heat release $\left(\mathrm{Q}, \mathrm{J} \mathrm{g}^{-1}\right)$ was determined by integrating the DSC curves (W

$\left.213 \mathrm{~g}^{-1}\right)$ on the exothermic region $\left(150-600^{\circ} \mathrm{C}\right)$. Data recorded at temperatures $<150{ }^{\circ} \mathrm{C}$ were

214 discarded because they are associated with the loss of mass and energy release during moisture

215 loss. The Q value was divided by the mass loss in each measurement ( $\mathrm{Q}^{\prime}, \mathrm{J} \mathrm{mg}^{-1} \mathrm{MO}$, Rovira et

216 al., 2008). 
Areas under the DSC curve were divided in three groups, representing different degrees

218 of resistance to thermal oxidation (Dell'Abate et al., 2002; Fernandez et al., 2012): labile organic

219 matter, comprising carbohydrates and other aliphatic compounds $\left(200-375^{\circ} \mathrm{C}\right)$; recalcitrant

220 organic matter such as lignin and / or polyphenols $\left(375-475^{\circ} \mathrm{C}\right)$; and extra-recalcitrant organic

221 matter, such as polycondensed aromatic forms $\left(475-550{ }^{\circ} \mathrm{C}\right)$. The heat release by combustion in

222 each region was designated as $\mathrm{Q}_{1}, \mathrm{Q}_{2}$ and $\mathrm{Q}_{3}$, respectively. Also, the temperature at which the

223 maximum heat flow was detected during the combustion of organic matter $\left(\mathrm{T}_{1}, \mathrm{~T}_{2}\right.$ and $\left.\mathrm{T}_{3}\right)$ and

224 the temperature at which $50 \%$ of the total energy was released were recorded $\left(\mathrm{T}_{50} \mathrm{DSC}\right)$.

2.4.3. Nutrient analysis

226 All forms of $\mathrm{C}$ were determined on a total carbon analyzer (UIC model CM5012, Chicago, USA)

227 by dry combustion and coulometric detection (Huffman, 1977), while forms of $\mathrm{N}$ were

228 determined colorimetrically by the semi-Kjeldahl (Bremmer, 1996) method and the forms of P

229 by molybdate colorimetric method after reduction with ascorbic acid (Riley \& Murphy, 1962) in

230 a Bran-Luebbe autoanalyzer (Autoanalyzer 3 Norderstedt, Germany) after acid digestion. The

231 litterfall chemical analyses were performed from material collected from the respective traps

232 (isolated Q. castanea, mixed species, and isolated Q. deserticola).

233 Soluble organic forms of $\mathrm{C}, \mathrm{N}$ and $\mathrm{P}$ were extracted from $2 \mathrm{~g}$ of fresh material in

234 deionized water, after stirring for 1 hour and filtered through a Whatman\# 42 filter and on a

235 vacuum system through a $0.45 \mu \mathrm{m}$ nitrocellulose membrane. The dissolved organic carbon

236 (DOC) was determined by combustion coulometric detection (Huffman, 1977). Dissolved

237 organic nitrogen (DON) and dissolved organic phosphorus (POD) were determined after acid

238 digestion. The DON was calculated as the difference between the acid digested nitrogen and 
239 soluble $\mathrm{NH}_{4}{ }^{+}$, as well as POD (acid digested P minus soluble inorganic P; Joergensen \& Mueller, 240 1996).

Microbial biomass carbon (Cmic) and nitrogen (Nmic) were determined by direct

242 extraction using chloroform fumigation (Brookes et al., 1984; Vance et al., 1987) from fresh

243 samples. Two subsamples $(2 \mathrm{~g})$ were incubated at $30^{\circ} \mathrm{C}$ for $24 \mathrm{~h}$; one of the subsamples was

244 maintained in chloroform atmosphere during incubation. Both samples were extracted in $0.5 \mathrm{M}$

$245 \mathrm{~K}_{2} \mathrm{SO}_{4}$ and percolated through \# 42 Whatman filter paper and analyzed as DOC (as mentioned

246 above) and removable $\mathrm{N}$. The extractable $\mathrm{N}$ was quantified as total $\mathrm{N}$ after acid digestion

247 (Brookes et al., 1984).

The microbial biomass P (Pmic) was determined by the fumigation-extraction method

249 (Brookes et al. 1982) in fresh samples. A subsample of $0.5 \mathrm{~g}$ was fumigated for $24 \mathrm{~h}$ in a

250 chloroform atmosphere and extracted with $30 \mathrm{~mL}$ of $0.5 \mathrm{M} \mathrm{NaHCO}_{3} \mathrm{pH} 8.5$ for 30 min (van

251 Meeteren et al., 2007). Extracts (fumigated and no-fumigated) were digested in a solution of

252 sulfuric acid and persulfate ammonium according to Hedley sequential $\mathrm{P}$ fractionation (Tiessen

253 \& Moir, 1993) and quantified as orthophosphate, as described above. Cmic concentration, Nmic

254 and Pmic were calculated from the difference between the fumigated and non-fumigated

255 samples, then the concentration was corrected by applying the following factors: $\mathrm{KeC} 0.45$

256 (Sparling et al., 1990), KeN 0.54 (Brookes et al., 1984; Jorgensen \& Mueller, 1996) and KeP

257 0.40, respectively (Brookes et al. 1982).

As a measurement of microbial activity related with the use of organic molecules, the enzymatic activities of $\beta$-1,4-glucosidase (BG), cellobiohydrolase (CBH), $\beta$-N-acetyl-glucosaminidase 
261 (NAG), polyphenol oxidase (POX) and dehydrogenase (DHG) were determined in fresh material

262 of each treatment for all samples collected. The determination of hydrolases (BG, $\mathrm{CBH}$ and

263 NAG) was performed according to Chávez-Vergara et al. (2014) by colorimetric measurement of

264 p-nitrophenol (pNP) in a spectrophotometer (Evolution 201, Thermo Scientific Inc.) at $420 \mathrm{~nm}$

265 liberated from specific substrates during incubation $\left(2 \mathrm{~h}\right.$ in oscillatory shaking at $\left.30^{\circ} \mathrm{C}\right)$ and

266 reported in g-mol pNP litter-1 $\mathrm{h}^{-1}$.

POX activity was determined through oxidation of 2, 2'-Azinobis [3-

268

269

270

271

272

273

274

275

276

277

278

279

280

281

282

283

ethylbenzothiazoline-6-sulfonic acid]-diammonium salt (ATBS). One aliquot of the same

extraction used for activity of hydrolases (Chávez-Vergara et al., 2014) was used, volume and

time of preparation were the same than for hydrolases but in this case the result of the

centrifugation was measured directly (without addition of $\mathrm{NaOH}$ and deionized water) on the

same spectrophotometer described above by colorimetry at $460 \mathrm{~nm}$ and the result was reported as mol tyrosine g-litter ${ }^{-1} \mathrm{~h}^{-1}$, in this case the calibration curve is derived from tyrosine (tyr).

The dehydrogenase activity (DHG) was determined according to a modification of the method described by Alef (1995), which is based on the reduction of chloride of 2, 3, 5triphenyltetrazolium (CTT) for the formation of triphenyltetrazolium formazan (TFF) in incubation at $30{ }^{\circ} \mathrm{C}$ for $24 \mathrm{~h}$. To perform the assay $0.5 \mathrm{~g}$ of milled fresh material was weighed and placed in a conical tube with a capacity of $15 \mathrm{~mL}$ (the tube was covered with foil to keep out light) to which $1 \mathrm{~mL}$ of a solution CTT 1\% in Tris buffer $\mathrm{pH} 7.6$ was added. Blank samples were prepared only with the solution of CTT. Subsequently, all samples were placed and horizontally fixed in an incubator chamber; the incubation was for $24 \mathrm{~h}$ at $30^{\circ} \mathrm{C}$ and $180 \mathrm{rpm}$. After incubation, $10 \mathrm{~mL}$ of acetone was added; the tube was stirred vigorously and allowed to react for $2 \mathrm{~h}$ in the dark at room temperature. Following, the supernatant was filtered through Whatman \# 
28442 paper and measured at $546 \mathrm{~nm}$ by colorimetry. The measure of each sample was subtracted

285 from the average value of blanks and adjusted by the equation described in Alef (1995). The

286 results were expressed in $\mathrm{g}$ TPF $\mathrm{g}^{-1} \mathrm{~d}^{-1}$.

287

The efficiency of enzymatic activity according to the concentration of a nutrient

288 immobilized in the microbial biomass was calculated as specific enzyme activity (SEA)

289 according to the following equation (Chávez-Vergara et al., 2014):

290 eq1. $\quad \mathrm{SEA}=\mathrm{A} / \mathrm{Bmic}$

291 where SEA is expressed in mol of pNP or mol of tyr released per milligram of nutrient in the

292 microbial biomass per hour $\left(\mathrm{mol} \mathrm{mg}^{-1} \mathrm{Bmic} \mathrm{h}^{-1}\right)$; $\mathrm{A}$ is the activity of any of the specific enzymes

293 (BG, CBH, NAG, POX and DHG), and Bmic is the concentration of Cmic or Nmic in $\mathrm{mg} \mathrm{g}^{-1}$.

294 The association of enzymes with nutrients in the microbial biomass is as follows: $\mathrm{BG}, \mathrm{CBH}$,

295 POX and DHG are associated with Cmic, and NAG with Nmic.

296

2.5. Statistical analysis

297

The initial nutrient concentration in the three litterfall conditions had five replicates, while the DSC and the ${ }^{13} \mathrm{C}$ NMR parameters had only one composite sample for each Quercus species, as well as the DSC and ${ }^{13} \mathrm{C}$ NMR parameters for the samples at 270 decomposition days. In contrast, the DSC parameter of the 30 decomposition days had a composite sample for each litter condition (litter origin and litter site, in total 9 samples). Therefore, the nutrient concentration of litterfall and DSC parameters according to litter quality and site effects at 30 days of decomposition were analyzed using one-way analyses of variance (ANOVA), while the remaining mass, total nutrient concentration and dissolved nutrients were analyzed with repeated measures ANOVA (RMANOVA), in which the between factor was litter species condition (QcL, 
306 QxL and QdL) and the within factors where sampling date (litterfall, and litter after 30 and 270

307 days of field decomposition, $\mathrm{n}=5$ ) and the interaction between litter condition and decomposition

308 time. The data of nutrients, enzymatic activities and specific enzymatic activities at 30 and 270

309 days of experiment were analyzed by a factorial ANOVA to test the effect of litter condition

310 (QcL, QdL and QxL) and site (QcS, QdS and QxS) in early and late decomposition. In this case,

311 all samples associated with each treatment in the factorial design $(n=15)$ were used. Afterwards,

312 statistically significant differences in one-way, RMANOVA and factorial ANOVA were

313 analyzed with the Tukey HSD post-hoc test.

314 To identify the relationship between the chemical quality of the litter and microbial

315 metabolism variables in the remaining mass at 30 days of decomposition, we performed

316 backward stepwise multiple regression analyses. As chemical quality variables, the C:N and C:P

317 ratios, dissolved forms of $\mathrm{C}, \mathrm{N}$ and $\mathrm{P}$ were used, while as microbial activity variables the specific

318 enzymatic activities were used for the multiple regression model. We performed a correlation

319 model using remaining mass and thermal parameters from the DSC analysis as indicators of litter

320 changes during early decomposition process. All analyses were made in the statistical package

321 Statistica 7.0 (StatSoft, USA).

322 The Home-Field Advantage Index (HFAI) proposed by Ayres et al. (2009) was calculated as the

323 percentage of mass loss of each litterfall condition (QcL, QXL, QdL) at the site where it was

324 produced relative to the mass loss at all sites (QcS, QXS, QdS):

325

Eq. 2.

$$
A_{R M L a}=\frac{A a}{A a+B a+C a} \times 100-100
$$


327 where, $\mathrm{A}_{\mathrm{RMLa}}$ represents the relative mass loss of litter from condition $\mathrm{A}$ at site a, and $\mathrm{Aa}, \mathrm{Ba}$ and

$328 \mathrm{Ca}$ represent the mass loss of litter from conditions $\mathrm{A}, \mathrm{B}$ and $\mathrm{C}$ decomposing at site a, 329 respectively. The measures of relative mass loss for each condition and site combination were 330 used to calculate HFAI.

331 Eq. 3 HFAI $=\left[\frac{A_{R M L a}+B_{R M L b}+C_{R M L C}}{3} / \frac{A_{M R L b}+A_{R M L C}+B_{R M L a}+B_{R M L C}+C_{R M L a}+C_{R M L b}}{6}\right] X 100-100$

\section{Results}

3.1. Mass loss and residence time

335

336

337

338

339

340

341

342

343

344

345

346

347

3.2. Chemical composition of litterfall and decomposed litter

3.2.1. ${ }^{13} \mathrm{C}$ CP MASS NMR characterization of litterfall samples 
348 Figure 2 shows the spectra and Table 1 the integration of regions of ${ }^{13} \mathrm{C}$ CPMAS NMR of

349 litterfall and decomposed litter at 270 days in both species. In the original litterfall, the most

350 prominent compounds were O-Alkyl, Aryl C and Alkyl C. Particularly, we observed that the

351 region between 160 and $220 \mathrm{ppm}$, assigned to carboxyl/ amide and carbonyl $\mathrm{C}$ groups, is

352 dominated by a peak at ca. 173 ppm (Fig. 2) with similar relative C distribution for both species

353 (Table 1). In the aromatic and phenolic region (160-110 ppm), the litterfall produced by both

354 species showed well defined peaks at ca. 153 and $145 \mathrm{ppm}$, which revealed the presence of C3,

355 C5 syringyl lignin and tannins, respectively. An incipient peak at ca. 131 in Q. deserticola and

356 well-defined in Q. castanea may be related to unsubstituted and C-substituted phenyl carbon of

357 lignin monomers of syringyl units (De Marco et al., 2012) affecting the S:G ratio between

358 species (Table 1). In the O-alkyl region $(45-110 \mathrm{ppm})$, the most prominent signal was at ca. 73

359 ppm and it was particularly associated to the simultaneous resonance of C-2, C-3 and C-5 of

360 pyranose rings in cellulose and hemi-cellulose; and a second prominent peak was at ca. 105 ppm,

361 traditionally associated to crystalline cellulose, and it can be associated to non-protonated carbon

362 arising from tannins (Almendros et al., 2000).

A shoulder at $56 \mathrm{ppm}$, attributable to N-methoxyl C compounds in lignin, was relatively

well resolved in litter samples of both species. Meanwhile, the C-6 position in the pyranose ring

of cellulose produced the peak or shoulder at ca. $64 \mathrm{ppm}$ better resolved in Q. castanea. In a similar way, that shoulder at 84 ppm may correspond to C-4 in cellulose (Almendros et al., 2000). The alkyl region (46-0 ppm) showed two well-defined peaks at 30 and $21 \mathrm{ppm}$. The peak at ca. $30 \mathrm{ppm}$ is related to polyethylene carbons in lipids and lipid polymers such as cutine or suberine and the peak at ca. $21 \mathrm{ppm}$ is frequently attributed to acetate groups in hemicellulose and/or short chain aliphatic structures. The most noticeable changes after 270 days of 
371 decomposition occur in the reduction of peak intensity in ca. $145 \mathrm{ppm}$ associated to tannins and

372 the increment of peaks at ca. 56 ppm (N-methoxyl) and two peaks in the alkyl C region (Fig. 2).

373 These changes were most intense in the $Q$. deserticola litter.

374 3.2.2. Thermal characteristics of litterfall samples by differential scanning calorimetry (DSC)

375 The litterfall thermograms of both species showed a bimodal shape (Figs. 3A and 3B). The first

376 peaks were situated at $347^{\circ} \mathrm{C}$ and $352^{\circ} \mathrm{C}$, and the second prominent peaks were at $449^{\circ} \mathrm{C}$ and

$377461^{\circ} \mathrm{C}$ for $Q$. castanea and Q. deserticola, respectively (Table 2). Additionally, the Qc litterfall

378 had a second peak at $424^{\circ} \mathrm{C}$ in the Q2 region. However, the energy released from the recalcitrant

379 region (Q2) was higher in the Q. castanea than in the Q. deserticola litterfall (Table 2). After 30

380 days of decomposition, the percentage of recalcitrant compounds (Q2) was higher in the Qc litter

381 than in the Qd litter, while the Qd litter had the highest percentage of extra-recalcitrant

382 compounds (Q3; Table 2; Fig. 3A and 3B). In the 270 days decomposed litter, the shape of the

383 thermogram of $Q$. castanea remained as bimodal, while for $Q$. deserticola the third peak at the

384 extra-recalcitrant region is well-defined and displaced to a higher temperature $\left(503^{\circ} \mathrm{C}\right.$; Fig. 3$)$.

385 The decomposed litter at 270 days increased the energy released, compared to 30 days, in the Q1

386 region $(\mathrm{Qc}+4 \%$ and $\mathrm{Qd}+2 \%)$, the Q2 region showed a decrease in the litter of both species (Qc

$387-7 \%$ and Qd -4\%; Table 2) and the Q3 region increased for both species but more for Q. castanea

$388(\mathrm{Qc}+63 \%$ and $\mathrm{Qd}+15 \%$; Table 2). The values of T50 were displaced to lower temperatures

389 (Table 2) in both species at 270 days of decomposition in comparison to 30 days of

390 decomposition.

391 In the one-way ANOVA of the thermal parameters at 30 days of decomposition,

392 recalcitrant and extra-recalcitrant compounds were the highest and the lowest in QcL and QdL,

393 respectively, without a significant effect of site (Table 3). Figure 4 shows the thermograms of 
394 litter at 30 days of decomposition of each Quercus species condition within each site. The QdL

395 showed the highest peak in the labile region at the three sites, while the QcL showed the highest

396 peak in the recalcitrant region also in the three sites. However, only the QdL showed a small

397 peak in the extra-recalcitrant region, mainly at the Qd site.

3.2.3. Nutrient concentration and stoichiometric ratios in litterfall and decomposed litter.

399

400

401

402

403

404

405

406

407

408

409

410

411

412

413

414

415

416

The concentration of $\mathrm{C}$ was only affected by decomposition time $(\mathrm{F}=3.5 ; \mathrm{p}<0.001)$ reducing its value at 270 days of decomposition (Table 4). In contrast, the interaction between litter quality and sampling date was significant for concentrations of $\mathrm{N}$ and $\mathrm{P}(\mathrm{F}=5.2, \mathrm{p}=0.01$ and $\mathrm{F}=5.5, \mathrm{p}=$ 0.009, respectively). The QdL had higher $\mathrm{N}$ concentration in all decomposition dates in comparison with QcL and QxL (Table 4). However, the QxL and the QdL had higher P concentration than QcL at 30 and 270 days of decomposition, but these values were similar in the three species litterfall (Table 4). These results suggest that the QxL and QdL had microbial P immobilization after 30 days of decomposition. Therefore, the $\mathrm{C}: \mathrm{N}$ and $\mathrm{C}: \mathrm{P}$ ratios were affected by litter quality and sampling date $(\mathrm{F}=25, \mathrm{p}=0.001$ and $\mathrm{F}=8.6, \mathrm{p}=0.004$, respectively $)$; the QcL had the highest values and the 270 days of decomposition had the lowest values for the three species conditions (Table 4). However, the N:P ratio was only affected by decomposition time $(\mathrm{F}=17, \mathrm{p}<0.001)$, where the highest and the lowest values were in the litterfall and at 30 days of decomposition, respectively (Table 4).

In contrast, the dissolved organic carbon and nitrogen (DOC and DON, respectively) concentrations were affected by the interaction of litter quality and sampling date $(\mathrm{F}=18$, $\mathrm{p}<0.001$ and $\mathrm{F}=21, \mathrm{p}<0.001$, respectively). The QdL had higher DOC concentration than the QcL in the two decomposition dates (Table 4), although the QxL had a higher DOC reduction at 270 days of decomposition than the QcL (64\% and 30\%, respectively). In contrast, the QcL had 
417 lower DON than the QxL and QdL in the litterfall and the litter at 270 days of decomposition,

418 but the three litters had no different DON values at 30 days of decomposition (Table 4).

419 Additionally, the QdL showed a reduction of DON concentration only at 270 days of

420 decomposition, while the litter of the two other species conditions had increments or no changes

421 in relation to their litterfall (QdL and QxL, respectively). The DOP concentration was affected

422 by both litter quality and sampling date $(F=18, p=0.002$ and $F=26, p<0.00001$, respectively); the

423 QdL and QcL had the highest and lowest DOP concentration, respectively, and the highest and

424 the lowest DOP values were at 30 and 270 decomposition days, respectively (Table 4).

425 Similarly, the dissolved inorganic forms of $\mathrm{N}\left(\mathrm{NH}_{4}{ }^{+}\right.$and $\left.\mathrm{NO}_{3}{ }^{-}\right)$were also affected by the

426 interaction between litter quality and sampling date $(F=66, p<0.001$ and $F=9, p=0.002$,

427 respectively). Both dissolved $\mathrm{NH}_{4}$ and $\mathrm{NO}_{3}$ concentrations were highest in the Qd and lowest in

428 the Qc in the litterfall, but this pattern changed at the 270 days of the experiment for $\mathrm{NH}_{4}^{+}$

429 concentration $\left(\mathrm{QcL}>\mathrm{QdL}=\mathrm{QxL}\right.$; Table 4) and for $\mathrm{NO}_{3}{ }^{-}$concentration $(\mathrm{Qd}>\mathrm{QxL}>\mathrm{QcL}$; Table 4).

430 The dissolved inorganic $\mathrm{P}$ form (DiP) was affected by the main factors $(\mathrm{F}=66, \mathrm{p}<0.001$ and

$431 \mathrm{~F}=26, \mathrm{p}<0.001$ for litter quality and sampling date, respectively); the QdL and QcL had the

432 highest and lowest DiP values, respectively, and the lowest DiP values were at 30 days of 433 decomposition (Table 4).

3.3. Microbial activity in decomposed litter.

436 The concentrations of microbial immobilized C, N and P (Cmic, Nmic and Pmic, respectively)

437 were highest in Qd, followed by Qx and lowest in Qc (Fig. 5) for litter decomposed on its

438 original site. However, the C:N, C:P and N:P microbial ratios were not affected by any factor 
439 analyzed (Fig. S1). The specific enzymatic activity of $\beta$-glucosidase (SEA BG), polyphenol

440 oxidase (SEA POX) and dehydrogenase (SEA DHG) showed the highest values in Qc and Qx

441 and the lowest values in Qd for litter decomposed on its original site (Fig. 6). At 30 days of

442 decomposition, the microbial immobilization of $\mathrm{C}$ responded to the main factors (litter condition

443 and site effects). The Qc site (QcS) had lower Cmic concentration than the other two sites (Fig.

444 5), while the Qd litter (QdL) had five-fold higher Cmic concentration than Qc (Fig. 5). However,

445 the litter conditions promoted only differences for Nmic and Pmic. In both cases, the QdL had

446 the highest concentrations, followed by the QxL, and the QcL had the lowest concentration

447 values (Fig. 5).

SEA DHG was affected by both main factors (site and litter); the QcS and litter had the

highest values (Fig. 6), SEA POX values were only affected by site, showing higher values in the

QcS than in the QdS (Fig. 6). Meanwhile the value of SEA BG was only influenced by litter

451 condition, with the QdL showing the lowest values (Fig. 6).

\section{3.4. Relation of variables with remaining mass}

453 The thermal parameters (heat released in the combustion from the DSC analysis) at 30 days of

454 decomposition had relationships with remaining mass; the $\mathrm{Q} 2\left(375-475^{\circ} \mathrm{C}\right)$ region was

455 positively related $(\mathrm{r}=0.77, \mathrm{p}=0.025)$, while the $\mathrm{Q} 3$ region $\left(475-550^{\circ} \mathrm{C}\right)$ was negatively related

$456(\mathrm{r}=-0.82, \mathrm{p}=0.001)$. Therefore, these parameters can be used as indicators of the intensity of the

457 decomposition process of litter (table 5). Also, in the multiple regression model, the remaining

458 mass at 30 days was positively explained by the $\mathrm{C}: \mathrm{N}$ ratio and negatively explained by DON,

459 DOP and dissolved $\mathrm{NH}_{4}{ }^{+}\left(\mathrm{R}^{2}=0.78, \mathrm{p}<0.001\right.$; Table 5). In addition, the remaining mass showed

460 a positive relation to SEA DHG and a negative relation to SEA POX $\left(r^{2}=0.38, p=0.033\right.$; Table

$4615)$. 


\section{Discussion}

464

Our results indicate that the factors which regulate litter decomposition are strongly affected by the decomposition date. At the early decomposition stage (30 days) when the labile molecules dominated, which regulate the decomposition rate (Berg, 2014), the coupling of litter quality and microbial activity (Home-Field Advantage hypothesis) is the main factor. However, at the advanced decomposition stage (270 days) when recalcitrant molecules dominated, the litter decomposition is regulated by the direct effect of the chemical composition of the plant residues (Substrate-Matrix Interaction hypothesis) and the legacy effect on the specialization of the microbial community in the use of organic compounds (Functional Breadth hypothesis). These conclusions are supported by the reduction of the Home-Field Advantage index with the

473 decomposition date ( $22 \%$ and $4 \%$ for 30 and 270 days, respectively). Therefore, the hypotheses 474 that have been raised to explain the process of decomposition of the litter are not mutually exclusive (Freschet et al., 2012; Fanin et al., 2016), which is only observable through crosssowing experiments such as the one elaborated in the present study.

For example, the litter of $Q$. deserticola, when decomposed under its own canopy, showed a greater mass loss after 30 and 270 days as expected by the Home- Field Advantage hypothesis. These results are explained by a higher concentration of total nutrient and dissolved organic forms concentrations, and lower concentration of recalcitrant compounds than in the other two sites, conditions which promotes microbial activity (Almendros et al., 2000; Aponte et al., 2013, Bonanomi et al., 2013; Fanin et al., 2013; Freschet et al., 2013; Osono et al., 2013). and 270 days of decomposition), we observed that this variable is explained by the type of litter 
485

486

487

488

489

490

491

492

493

494

495

496

497

498

499

500

501

502

503

504

505

506

507

and by the site where it decomposes, since the material of $Q$. deserticola $(\mathrm{QdL})$ loses more mass independently of the site where it decomposes, but it is in the sites of $Q$. castanea $(\mathrm{QcS})$ and in the species mixture $(\mathrm{QxS})$ where more mass is lost regardless of its origin. These results, suggest that the condition of the two other sites $(\mathrm{QcS}$ and $\mathrm{QxS})$ decrease the importance of the HomeField Advantage hypothesis, mainly at 270 decomposition days.

The mechanisms that explain the higher rate of mass loss in the litterfall of $Q$. deserticola are probably related to its chemical composition, since the higher concentrations of COD and N and $\mathrm{P}$ in soluble forms decrease the investment in energy of the microbial community for the production of exo-enzymes to obtain organic compounds of low molecular weight (Baldrian et al., 2010; Glanville et al., 2012; Allison et al., 2014).

In contrast, in places with natural incorporation of low quality material for decomposition, as the Qc site, the microbial community makes metabolic adjustments related to the chemical characteristics of the litter, which is also a key factor in the rate of decomposition. In this regard, we observed that when leaf litter of better chemical quality (QdL) is incorporated in the $Q$. castanea $(\mathrm{QcS})$ site and in the mixed species site $(\mathrm{QxS})$, it decomposes at a faster rate than in the site where it was produced, and also increases the immobilization of nutrients in the microbial biomass, mainly in the early decomposition stage (30 days). These results suggest that the microbial community of the litter under $Q$. castanea is more efficient in obtaining and using organic compounds, because of the continuous exposure to low quality litter (Van Meeteren et al., 2007; Baldrian et al., 2012; Allison et al., 2014; Chávez-Vergara et al., 2014; ChávezVergara et al., 2016), supporting the Functional Breadth hypothesis. the Q. castanea site, the microbial community of this site maintained a high SEA of POX and 
508 SEA of DG and did not modify the stoichiometric ratios in the microbial biomass. This indicates

509 that the microbial community maintains carbon efficiency in a similar way than when it is

510 exposed to the local litter, using more energy in the production of enzymes for the

511 depolymerization of recalcitrant compounds than in the accumulation of biomass (Chávez-

512 Vergara et al., 2014; Chávez-Vergara et al., 2016; Zederer et al., 2017). Therefore, we suggest

513 that the greater availability of nutrients in the best quality litter ( $Q$. deserticola) stimulates the

514 growth of microbial populations, but nevertheless these populations maintain their ability to use

515 recalcitrant compounds, in overall making the microbial community under Q. castanea more

516 efficient in the decomposition of the litter, mainly at the advanced decomposition stage (270

517 days). This can be considered as a legacy effect on the microbial community of low quality

518 compounds for decomposition (Fanin et al., 2016). In a previous work (Chávez-Vergara et al.,

519 2016), we determined that the chemical composition of the litter influenced the composition of

520 the fungal community. Under Q. castanea a greater proportion of basidiomycetes was observed,

521 which have been reported to be specialized in the degradation of recalcitrant compounds (Osono

$522 \&$ Takeda., 2002, Snajdr et al., 2011). Therefore, the composition of the microbial community

523 reflects the physiological footprint of the plant (Wickings et al., 2012) and constitutes a legacy of

524 the chemical traits of plant species (Wurst \& Ohgushi, 2015; García-Palacios et al., 2016).

In general, we can suggest that the better litter quality regulates the accessibility of

526

527

528

529

530 organic compounds for their use (Prescott 2010; Wickings et al., 2012; Freschet et al., 2013),

while the microbial community, through its specialization, determines the efficiency in its use and therefore the speed of decomposition (Strickland et al., 2009; Snajdr et al., 2011; Cleveland et al., 2014). The above can explain the observed patterns in the thermal analysis of the decomposed material at 30 days. In the thermal analysis, we observed that it is at the Qc site that 
531 the signal of the recalcitrant compounds is more intensely decreased, and it is at this site, as

532 mentioned above, that there is a greater investment in the production of enzymes for the

533 degradation of recalcitrant compounds. Likewise, it is at this site that a clear signal of reactive

534 molecules derived from microbial metabolic activity is observed, which is inferred by the

535 appearance of an exothermic peak $\left(\mathrm{ca} 500^{\circ} \mathrm{C}\right)$ in the region of extra-recalcitrant compounds

536 (Rovira et al., 2008). This suggests that it is at this site that a more intense transformation of

537 microbial organic compounds occurs, more clearly detected with thermal analysis (DSC) than in 538 the analysis of ${ }^{13} \mathrm{C}$ NMR.

539

\section{5. Conclusions}

541 In this study, we observed that the importance of the coupling of litter quality and microbial

542 activity depends on decomposition stage. At early decomposition stage, the Home-Field

543 Advantage hypothesis explained the mass loss of litter; however, in the advanced decomposition

544 stage, the litter quality and the metabolic capacity of the microbial community can be the key

545 drivers, mainly under Q. castanea conditions (litter with low available nutrients). These results

546 enhance our knowledge about the mechanisms that regulate the decomposition of the litter in oak

547 deciduous forests.

\section{Acknowledgements}

550 The authors thank Rodrigo Velázquez and Ofelia Beltrán for field and laboratory assistance. We

551 thank two Anonymous reviewers for comments on a draft of the manuscript. B. Chávez-Vergara 
552 acknowledges the support from the Graduate Program in Biological Sciences of the National

553 Autonomous University of México

554 (UNAM).

555

556 Literature cited

557 Ågren GI, Hyvönen R, Berglund SL, Hobbie SE. 2013. Estimating the critical N:C from litter 558 decomposition data and its relation to soil organic matter stoichiometry. Soil Biology and 559 Biochemistry 67:312-318. DOI: 10.1016/j.soilbio.2013.09.010

560 Alef K. 1995. Dehydrogenase activity. In: Alef, K., Nannipieri, P. eds. Methods in Applied Soil 561 Microbiology and Biochemistry. Academic Press, San Diego, California, 228-231.

562 Allison SD, Chacon SS, German DP. 2014. Substrate concentration constrains on microbial 563 decomposition. Soil Biology and Biochemistry 79:43-49. DOI: 10.1016/j.soilbio.2014.08.021

564 Almendros G, Dorado J, González-Villa FJ, Blanco MJ, Lankes U. 2000. 13C NMR assessment 565 of decomposition patterns during composting of forest and shrub biomass. Soil Biology and 566 Biochemistry 32:793-804. DOI: 10.1016/S0038-0717(99)00202-3.

567 Angehrn-Bettinazzi C, Lüscher P, Hertz J. 1988. Thermogravimetry as a method for 568 distinguishing various degrees of mineralization in macromorphologically defined humus 569 horizons. Zeitschrift für Pflanzenernährung und Bodenkunde 151:177-183. DOI: $570 \quad 10.1002 / j p \ln .19881510305$ 
571 Aponte C, García LV, Marañón T. 2013. Tree species effects on nutrient cycling and soil biota:

572 A feedback mechanism favoring species coexistence. Forest Ecology and Management 309:36-

573 46. DOI: 10.1016/j.foreco.2013.05.035

574 Austin AT, Vivanco L, Gonzalez-Arzac A, Perez LI. 2014. There's no place like home? An 575 exploration of the mechanisms behind plant litter-decomposer affinity in terrestrial ecosystems. 576 New Phytologist 204:307-314 DOI: 10.1111/nph.12959

577 Austin AT, Yahdjian L, Stark JM, Belnap J, Porporato A, Norton U, Ravetta DA, Schaeffer SM. 578 2004. Water pulses and biogeochemical cycles in arid and semiarid ecosystems. Oecologia 579 141:221-235. DOI: 10.1007/s00442-004-1519-1

580 Ayres E, Steltzer H, Simmons BL, Simpson RT, Steinweg JM, Wallenstein MD, Mellor N, 581 Parton WJ, Moore JC, Wall DH. 2009. Home-field advantage accelerates leaf litter 582 decomposition in forests. Soil Biology and Biochemistry 41:606-610. DOI: 583 10.1016/j.soilbio.2008.12.022

584 Baas WJ. 1989. Secondary plant compounds, their ecological significance and consequences for 585 the carbon budget: intro duction to the carbon/nutrient-cycle theory. In: Lambers H, Cambridge 586 ML, Konings H, Pons TL eds. Causes and consequences of variation in growth rate and 587 productivity of higher plants. SPB Acad. Publ., The Hague, pp. 313-340

588 Baldrian P, Lopez-Mondejar R. 2014. Microbial genomics, transcriptomics and proteomics: new 589 discoveries in decomposition research using complementary methods. Applied Microbiology and 590 Biotechnology 98:1531-1537. DOI: 10.1007/s00253-013-5457-x 
591 Baldrian P, Merhautová V, Cajthaml T, Petránková M, Šnajdr J. 2010. Small-scale distribution 592 of extracellular enzymes, fungal, and bacterial biomass in Quercus petraea forest topsoil. 593 Biology and Fertility of Soils 46:717-726. DOI: 10.1007/s00374-010-0478-4

594 Baldrian P, Kolarik M, Stursova M, Kopecky J, Valaskova V, Vetrovsky T, Zifcakova L, Snajdr 595 J, Ridl J, Vlcek C, Voriskova J. 2012. Active and total microbial communities in forest soil are 596 largely different and highly stratified during decomposition. ISME Journal 6:248-258. DOI: $597 \quad 10.1038 /$ ismej.2011.95

598 Baldrian P, Lopez-Mondejar R. 2014. Microbial genomics, transcriptomics and proteomics: new 599 discoveries in decomposition research using complementary methods. Applied Microbiology and 600 Biotechnology 98:1531-1537. DOI: 10.1007/s00253-013-5457-x

601 Barros N, Salgado J, Feijóo S. 2007. Calorimetry and soil. Thermochimica Acta 458:11-17.

602 Berg B. 2014. Decomposition patterns for foliar litter - A theory for influencing factors. Soil 603 Biology and Biochemistry 78:222-232. DOI: 10.1016/j.soilbio.2014.08.005.

604 Bonanomi G, Incerti G, Giannino F, Mingo A, Lanzotti V, Mazzoleni S. 2013. Litter quality 605 assessed by solid state $13 \mathrm{C}$ NMR spectroscopy predicts decay rate better than $\mathrm{C} / \mathrm{N}$ and Lignin $/ \mathrm{N}$ 606 ratios. Soil Biology and Biochemistry 56:40-48. DOI: 10.1016/j.soilbio.2012.03.003

607 Bremmer JM. 1996. Nitrogen-total. In: Spark DL, Page AL, Summer ME, Tabatabai MA, 608 Helmke PA. eds. Methods of Soil Analyses Part 3: Chemical Analyses. Soil Science Society of 609 America, Madison WI, pp. 1085-1121.

610 Brookes PC, Powlson DS, Jenkinson DS. 1982. Measurement of microbial biomass phosphorus 611 in soil. Soil Biology and Biochemistry 14:319-329. DOI: 10.1016/0038-0717(82)90001-3 
612 Brookes PC, Powlson DS, Jenkinson DS. 1984. Phosphorus in the soil microbial biomass. Soil 613 Biology and Biochemistry 16:169-175. DOI: 10.1016/0038-0717(84)90108-1.

614 Chavez-Vergara B, Merino A, Vázquez-Marrufo G, García-Oliva F. 2014. Organic matter 615 dynamics and microbial activity during decomposition of forest floor under two native 616 neotropical oak species in a temperate deciduous forest in Mexico. Geoderma 235-236:133-145. 617 DOI: 10.1016/j.geoderma.2014.07.005

618 Chávez-Vergara B, Rosales-Castillo A, Merino A, Vázquez-Marrufo G, Oyama K, García-Oliva 619 F. 2016. Quercus species control nutrients dynamics by determining the composition and activity 620 of the forest floor fungal community. Soil Biology and Biochemistry 98:186-195. DOI: 621 10.1016/j.soilbio.2016.04.015

622 Chávez-Vergara BM, González-Rodríguez A, Etchevers JD, Oyama K, García-Oliva F. 2015. 623 Foliar nutrient resorption constrains soil nutrient transformations under two native oak species in 624 a temperate deciduous forest in Mexico. European Journal of Forest Research 134:803-817. 625 DOI: $10.1007 / \mathrm{s} 10342-015-0891-1$

626 Cleveland CC, Neff JC, Townsend AR, Hood E. 2004. Composition, Dynamics, and Fate of 627 Leached Dissolved Organic Matter in Terrestrial Ecosystems: Results from a Decomposition 628 Experiment. Ecosystems 7:275-285. DOI: 10.1007/s10021-003-0236-7

629 Cleveland CC, Reed SC, Keller AB, Nemergut DR, O'Neill SP, Ostertag R, Vitousek PM. 2014. 630 Litter quality versus soil microbial community controls over decomposition: a quantitative 631 analysis. Oecologia 174:283-294. DOI: 10.1007/s00442-013-2758-9

632 De Marco A, Spaccini R, Vittozzi P, Esposito F, Berg B, Virzo De Santo A. 2012. 633 Decomposition of black locust and black pine leaf litter in two coeval forest stands on Mount 
634 Vesuvius and dynamics of organic components assessed through proximate analysis and NMR 635 spectroscopy. Soil Biology and Biochemistry 51:1-15. DOI: 10.1016/j.soilbio.2012.03.025

636 Dell' Abate MT, Benedetti A, Trinchera A, Dazzi C. 2002. Humic substances along the profile 637 of two Typic Haploxerert. Geoderma 107:281-296. DOI: 10.1016/S0016-7061(01)00153-7.

638 Fanin N, Fromin N, Bertrand I. 2016. Functional breadth and home-field advantage generate 639 functional differences among soil microbial decomposers. Ecology 97:1023-1037. DOI: $640 \quad 10.1890 / 15-1263.1$

641 Fanin N, Fromin N, Buatois B, Hattenschwiler S. 2013. An experimental test of the hypothesis of 642 non-homeostatic consumer stoichiometry in a plant litter-microbe system. Ecology Letters 643 16:764-772. DOI: 10.1111/ele.12108

644 Fernández JM, Plaza C, Polo A, Plante AF. 2012. Use of thermal analysis techniques (TG-DSC) 645 for the characterization of diverse organic municipal waste streams to predict biological stability 646 prior to land application. Waste Management 32:158-164. DOI: 10.1016/j.wasman.2011.08.011

647 Freschet GT, Aerts R, Cornelissen JHC. 2012. Multiple mechanisms for trait effects on litter 648 decomposition: moving beyond home-field advantage with a new hypothesis. Journal of Ecology 649 100:619-630. DOI: 10.1111/j.1365-2745.2011.01943.x

650 Freschet GT, Cornwell WK, Wardle DA, Elumeeva TG, Liu W, Jackson BG, Onipchenko VG, 651 Soudzilovskaia NA, Tao J, Cornelissen JHC, Austin A. 2013. Linking litter decomposition of 652 above- and below-ground organs to plant-soil feedbacks worldwide. Journal of Ecology 653 101:943-952. DOI: 10.1111/1365-2745.12092 
654 Garcia-Palacios P, Shaw EA, Wall DH, Hattenschwiler S. 2016. Temporal dynamics of biotic 655 and abiotic drivers of litter decomposition. Ecology Letters 19:554-563. DOI: 10.1111/ele.12590

656 Genung MA, Bailey JK, Schweitzer JA. 2013. The afterlife of interspecific indirect genetic 657 effects: genotype interactions alter litter quality with consequences for decomposition and 658 nutrient dynamics. PLoS One 8:e53718. DOI: 10.1371/journal.pone.0053718

659 Gessner MO, Swan CM, Dang CK, McKie BG, Bardgett RD, Wall DH, Hattenschwiler S. 2010. 660 Diversity meets decomposition. Trends in Ecology and Evolution 25:372-380. DOI: $661 \quad 10.1016 /$ j.tree.2010.01.010

662 Glanville H, Rousk J, Golyshin P, Jones DL. 2012. Mineralization of low molecular weight 663 carbon substrates in soil solution under laboratory and field conditions. Soil Biology and 664 Biochemistry 48:88-95. DOI: 10.1016/j.soilbio.2012.01.015

665 Hicks Pries CE, Bird JA, Castanha C, Hatton PJ, Torn MS. 2017. Long term decomposition: the 666 influence of litter type and soil horizon on retention of plant carbon and nitrogen in soils. 667 Biogeochemistry 134:5-16. DOI: 10.1007/s10533-017-0345-6

668 Huffman EWD. 1977. Performance of a new carbon dioxide coulometer. Microchemical Journal 669 22:567-573. DOI: 10.1016/0026-265X(77)90128-X

670 Joergensen RG, Mueller T. 1996. The fumigation-extraction method to estimate soil microbial

671 biomass: Calibration of the KEN value. Soil Biology and Biochemistry 28:33-37. DOI: $67210.1016 / 0038-0717(95) 00101-8$ 
673 Leifeld J, Kögel-Knabner I. 2005. Soil organic matter fractions as early indicators for carbon 674 stock changes under different land-use. Geoderma 124:143-155. DOI: 675 10.1016/j.geoderma.2004.04.009.

676 Makkonen M, Berg MP, van Logtestijn RSP, van Hal JR, Aerts R. 2013. Do physical plant litter 677 traits explain non-additivity in litter mixtures? A test of the improved microenvironmental 678 conditions theory. Oikos 122:987-997. DOI: 10.1111/j.1600-0706.2012.20750.x

679 Murphy J, Riley JP. 1962. A modified single solution method for the determination of phosphate 680 in natural waters. Analytica Chimica Acta 27:31e36. DOI: 10.1016/S0003-2670(00)88444-5

681 Nguyen Tu TT, Egasse C, Zeller B, Bardoux G, Biron P, Ponge JF, David B, Derenne S. 2011. 682 Early degradation of plant alkanes in soils: A litterbag experiment using 13C-labelled leaves. 683 Soil Biology and Biochemistry 43:2222-2228. DOI: doi:10.1016/j.soilbio.2011.07.009

684 Olsen JS. 1963. Energy storage and the balance of producers and decomposers in ecological 685 systems. Ecology 44:322-331.

686 Ono K, Hiradate S, Morita S, Hirai K. 2011. Fate of organic carbon during decomposition of 687 different litter types in Japan. Biogeochemistry 112:7-21. DOI: 10.1007/s10533-011-9682-z

688 Osono T, Azuma J-i, Hirose D. 2013. Plant species effect on the decomposition and chemical 689 changes of leaf litter in grassland and pine and oak forest soils. Plant and Soil 376:411-421. 690 DOI: $10.1007 / \mathrm{s} 11104-013-1993-5$

691 Osono T, Takeda H. 2002. Comparison of litter decomposing ability among diverse fungi in a 692 cool temperate deciduous forest in Japan. Mycologia 94:421-427. 
693 Pearse IS, Cobb RC, Karban R, Aerts R. 2014. The phenology-substrate-match hypothesis 694 explains decomposition rates of evergreen and deciduous oak leaves. Journal of Ecology 102:28695 35. DOI: $10.1111 / 1365-2745.12182$

696 Prescott CE. 2010. Litter decomposition: what controls it and how can we alter it to sequester 697 more carbon in forest soils? Biogeochemistry 101:133-149. DOI: 10.1007/s10533-010-9439-0

698 Rovira P, Kurz-Besson C, Coûteaux M-M, Ramón Vallejo V. 2008. Changes in litter properties 699 during decomposition: A study by differential thermogravimetry and scanning calorimetry. Soil 700 Biology and Biochemistry 40:172-185. DOI: 10.1016/j.soilbio.2007.07.021

701 Snajdr J, Cajthaml T, Valaskova V, Merhautova V, Petrankova M, Spetz P, Leppanen K, 702 Baldrian P. 2011. Transformation of Quercus petraea litter: successive changes in litter 703 chemistry are reflected in differential enzyme activity and changes in the microbial community 704 composition. FEMS Microbiology Ecology 75:291-303. DOI: $10.1111 / \mathrm{j} .1574-$ 705 6941.2010.00999.x

706 Spaccini R, Mbagwu JSC, Conte P, Piccolo A. 2006. Changes of humic substances 707 characteristics from forested to cultivated soils in Ethiopia. Geoderma 132:9-19. DOI: 708 10.1016/j.geoderma.2005.04.015

709 Sparling GP, Feltham CW, Reynolds J, West AW. 1990. Estimation of soil microbial C by a 710 fumigation-extraction method: use on soils of high organic matter content, and a reassessment of 711 the KEC-factor. Soil Biology and Biochemistry 22, 301-307. DOI: 10.1016/0038$712 \quad 0717(90) 90104-8$.

713 StatSoft, Inc. 2014. STATISTICA (data analysis software system), version 12. 714 www.statsoft.com. 
715 Strickland MS, Osburn E, Lauber C, Fierer N, Bradford MA. 2009. Litter quality is in the eye of

716 the beholder: initial decomposition rates as a function of inoculum characteristics. Functional

717 Ecology 23:627-636. DOI: 10.1111/j.1365-2435.2008.01515.x

718 Talbot JM, Bruns TD, Taylor JW, Smith DP, Branco S, Glassman SI, Erlandson S, Vilgalys R, 719 Liao HL, Smith ME, Peay KG. 2014. Endemism and functional convergence across the North 720 American soil mycobiome. Proceedings of the National Academy of Sciences 111:6341-6346.

721 DOI: 10.1073/pnas.1402584111

722 Talbot JM, Yelle DJ, Nowick J, Treseder KK. 2012. Litter decay rates are determined by lignin 723 chemistry. Biogeochemistry 108:279-295. DOI: 10.1007/s10533-011-9599-6

724 Tiessen H, Moir JO. 1993. Characterization of available P by sequential extraction. In: Carter 725 MR, ed. Soil sampling and methods of analysis: Lewis Publishers, 75-85.

726 Van Meeteren MJM, Tietema A, Westerveld JW. 2007. Regulation of microbial carbon, 727 nitrogen, and phosphorus transformations by temperature and moisture during decomposition of 728 Calluna vulgaris litter. Biology and Fertility of Soils 44:103-112. DOI: 10.1007/s00374-007$729 \quad 0184-\mathrm{Z}$

730 Vance ED, Brookes PC, Jenkinson DS. 1987. An extraction method for measuring soil microbial 731 biomass C Soil Biology and Biochemistry. 19, 703-707. DOI: 10.1016/0038-0717(87)90052-6.

732 Wickings K, Grandy AS, Reed SC, Cleveland CC. 2012. The origin of litter chemical 733 complexity during decomposition. Ecology Letters 15:1180-1188. DOI: 10.1111/j.1461$734 \quad 0248.2012 .01837 . x$ 
735 Wurst S, Ohgushi T, Allen E. 2015. Do plant- and soil-mediated legacy effects impact future 736 biotic interactions? Functional Ecology 29:1373-1382. DOI: 10.1111/1365-2435.12456

737 Zederer DP, Talkner U, Spohn M, Joergensen RG. 2017. Microbial biomass phosphorus and $738 \mathrm{C} / \mathrm{N} / \mathrm{P}$ stoichiometry in forest floor and A horizons as affected by tree species. Soil Biology and 739 Biochemistry 111:166-175. DOI: 10.1016/j.soilbio.2017.04.009 


\title{
Figure 1
}

Remaining mass in litterbags after 30 and 270 decomposition days

\begin{abstract}
A) Remaining mass in litterbags after 30 and 270 days of decomposition in the field for each litter condition decomposed in the same site of production, B) Effect of litter quality over remaining mass at 30 days and 270 days, and C) Effect of site over remaining mass at 30 and 270 days. Different capital letters indicate differences among conditions at 30 days and lowercase letters indicate differences among conditions at 270 days.
\end{abstract}




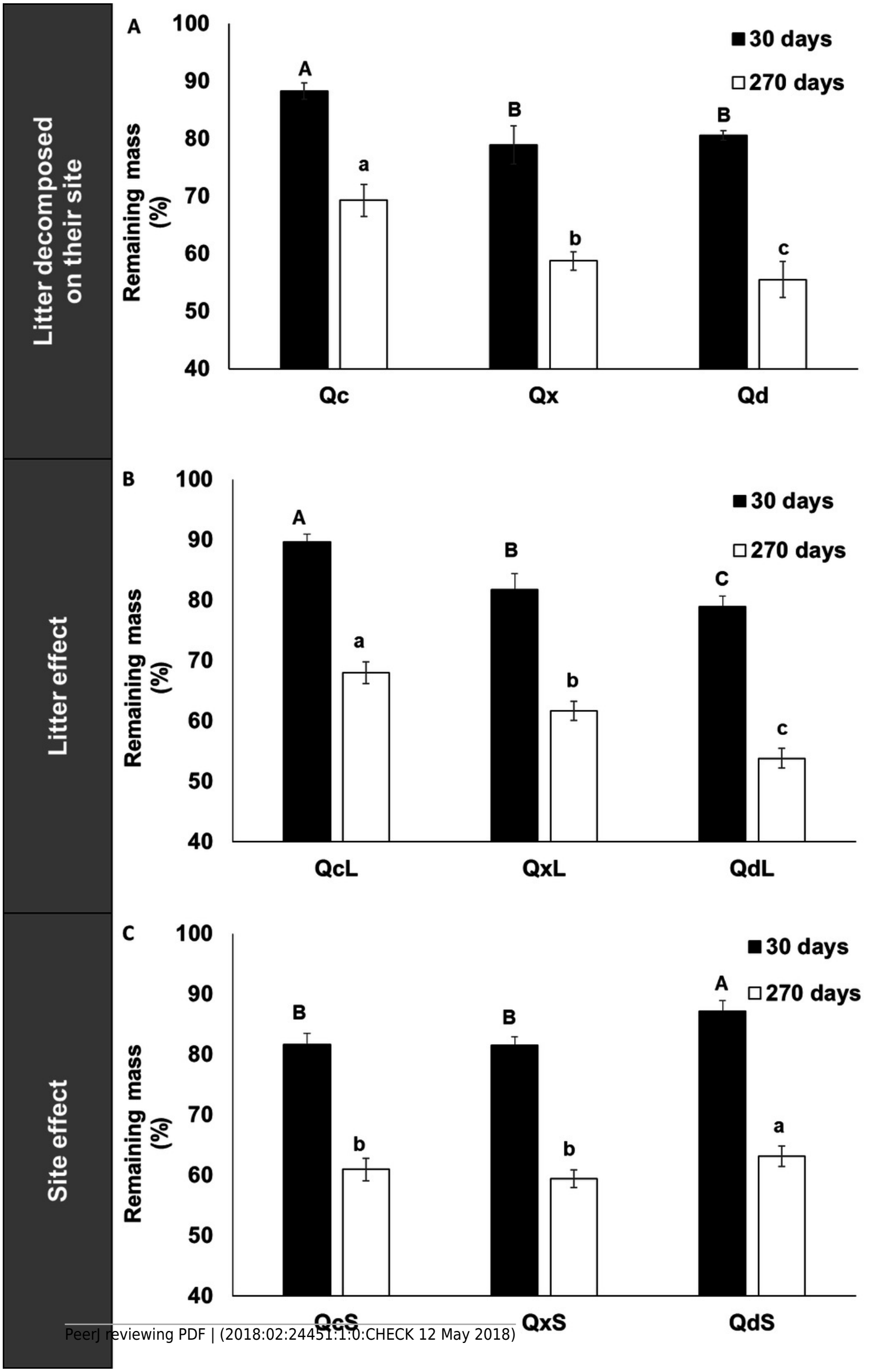




\section{Figure 2}

\section{${ }^{13} \mathrm{C}$ CPMAS NMR spectrograms}

Litter decomposing on their site: A) Quercus castanea litterfall (solid line) and decomposed litter (dotted line) and B) Quercus deserticola litterfall (solid line) and decomposed litter (dotted line). 
A

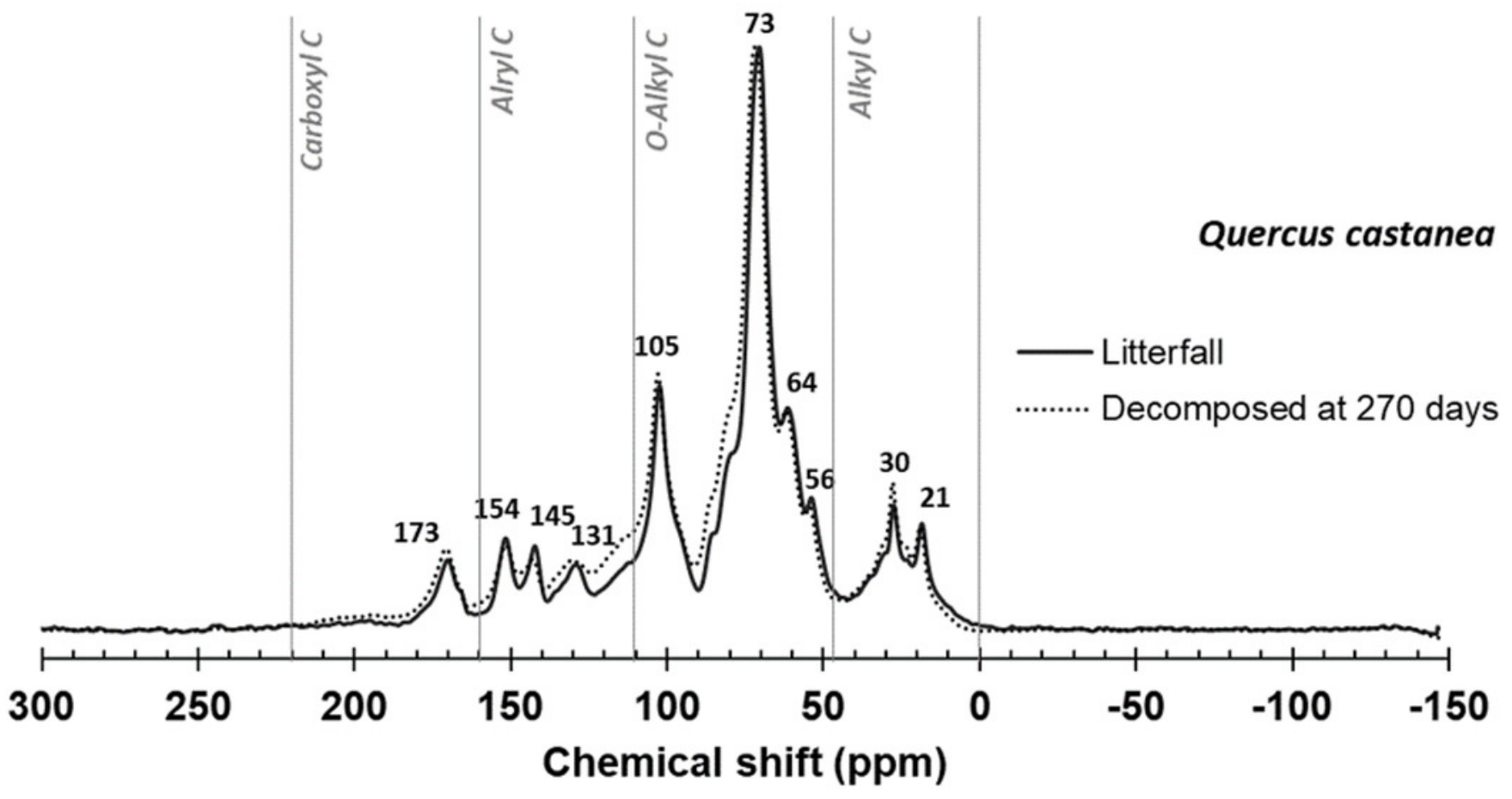

B

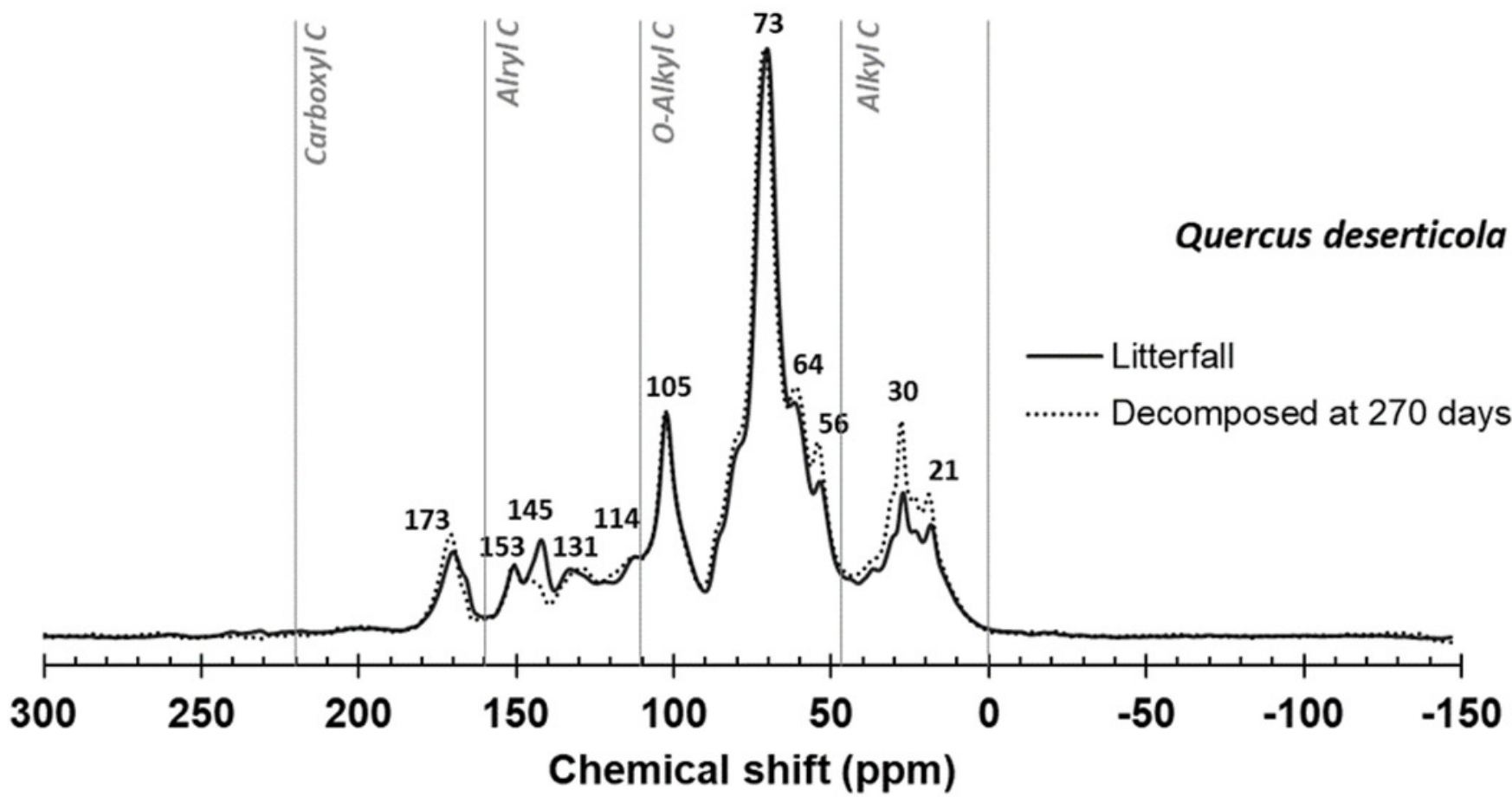




\section{Figure 3}

\section{DSC thermogams}

Litter decomposing on their site: A) Quercus castanea and B) Quercus deserticola litterfall (solid line), decomposed at 30 days (broad dotted lines) and decomposed at 270 days (fine dotted lines). 

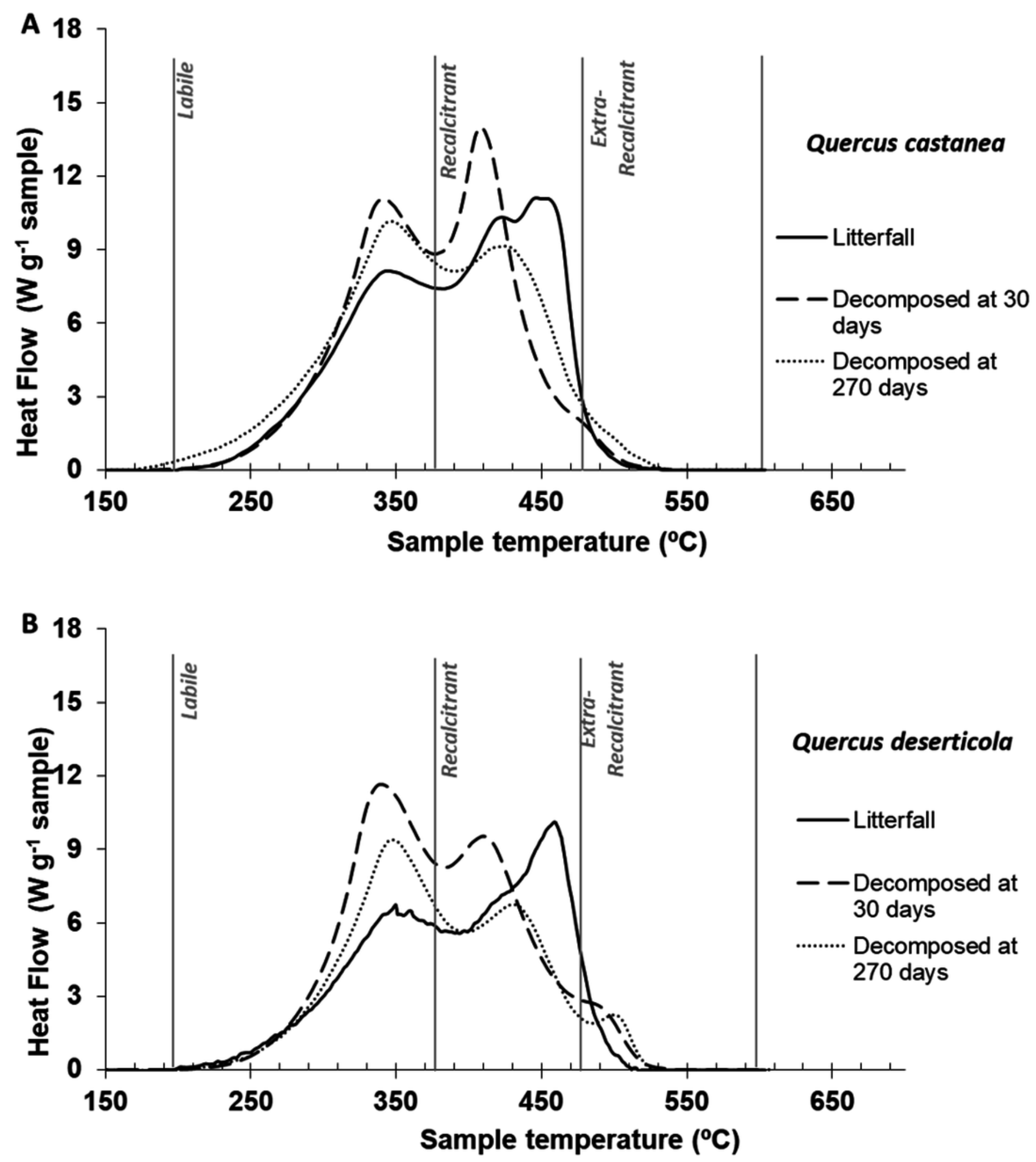


\section{Figure 4}

DSC thermogams of each litter condition decomposed

DSC thermograms of each litter condition decomposed on A) Quercus castanea site, B) mixed species site and C) Quercus deserticola site. Q. castanea litter (Qc, solid line), mixed species litter (Qx broad dotted lines) and $Q$. deserticola litter (Qd, fine dotted lines). 

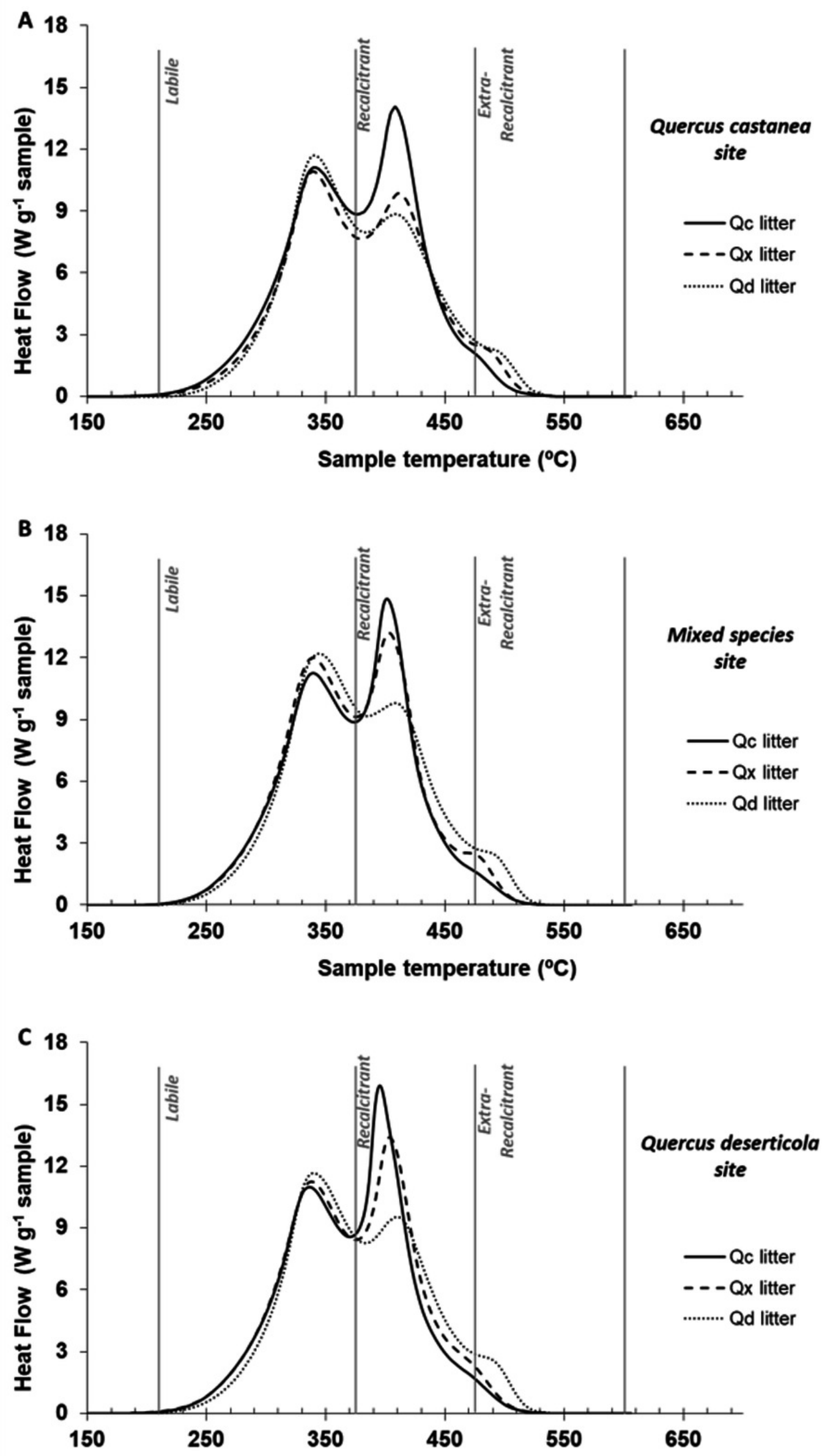

PeerJ reviewing PDF | (2018:02:Samsuples: tenmperatuare2(98)) 


\section{Figure 5}

Microbial immobilization of $\mathrm{C}, \mathrm{N}$ and $\mathrm{P}$ in litter decomposed

Microbial immobilization of $\mathrm{C}, \mathrm{N}$ and $\mathrm{P}$ in litter decomposed on its original site (A-C), litter effect (D-F) and site effect (G-I). Quercus castanea (QC), Mixed species (Qx) and Quercus deserticola (Qd). The suffixes -L and $-S$ refer to litter and site, respectively. Different letters indicate statistical differences $(p<0.05)$ according to the ANOVA model.
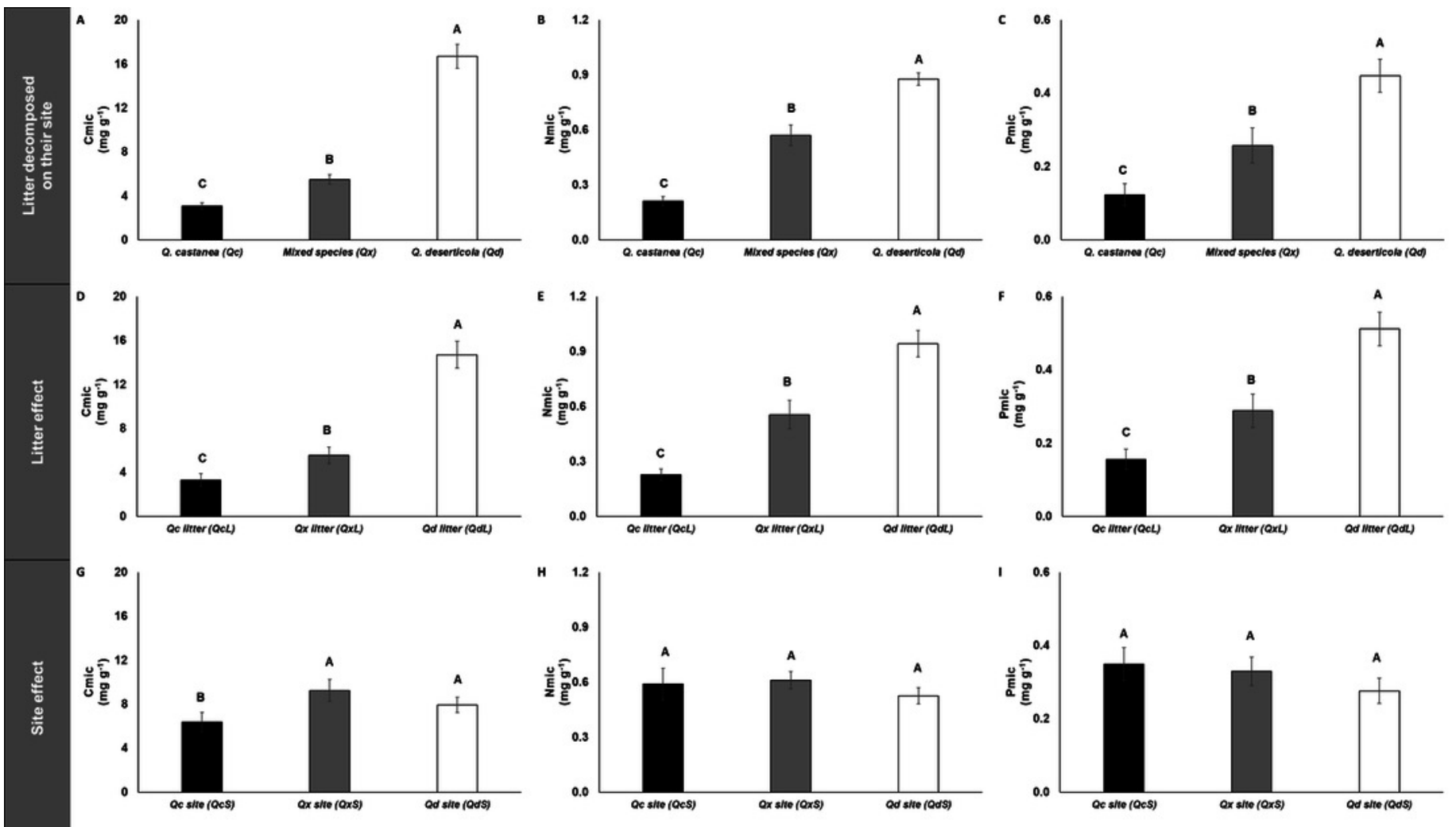


\section{Figure 6}

Specific enzymatic activities of dehydrogenase, $\beta$-glucosidase and polyphenol oxidase in litter decomposed.

Specific enzymatic activities of dehydrogenase, $\beta$-glucosidase and polyphenol oxidase in litter decomposed on its original site (A-C), litter effect (D-F) and site effect (G-I). Quercus castanea (QC), Mixed species (Qx) and Quercus deserticola (Qd). The suffixes $-L$ and $-S$ refer to litter and site, respectively. Different letters indicate statistical differences $(p<0.05)$ according to the ANOVA model.
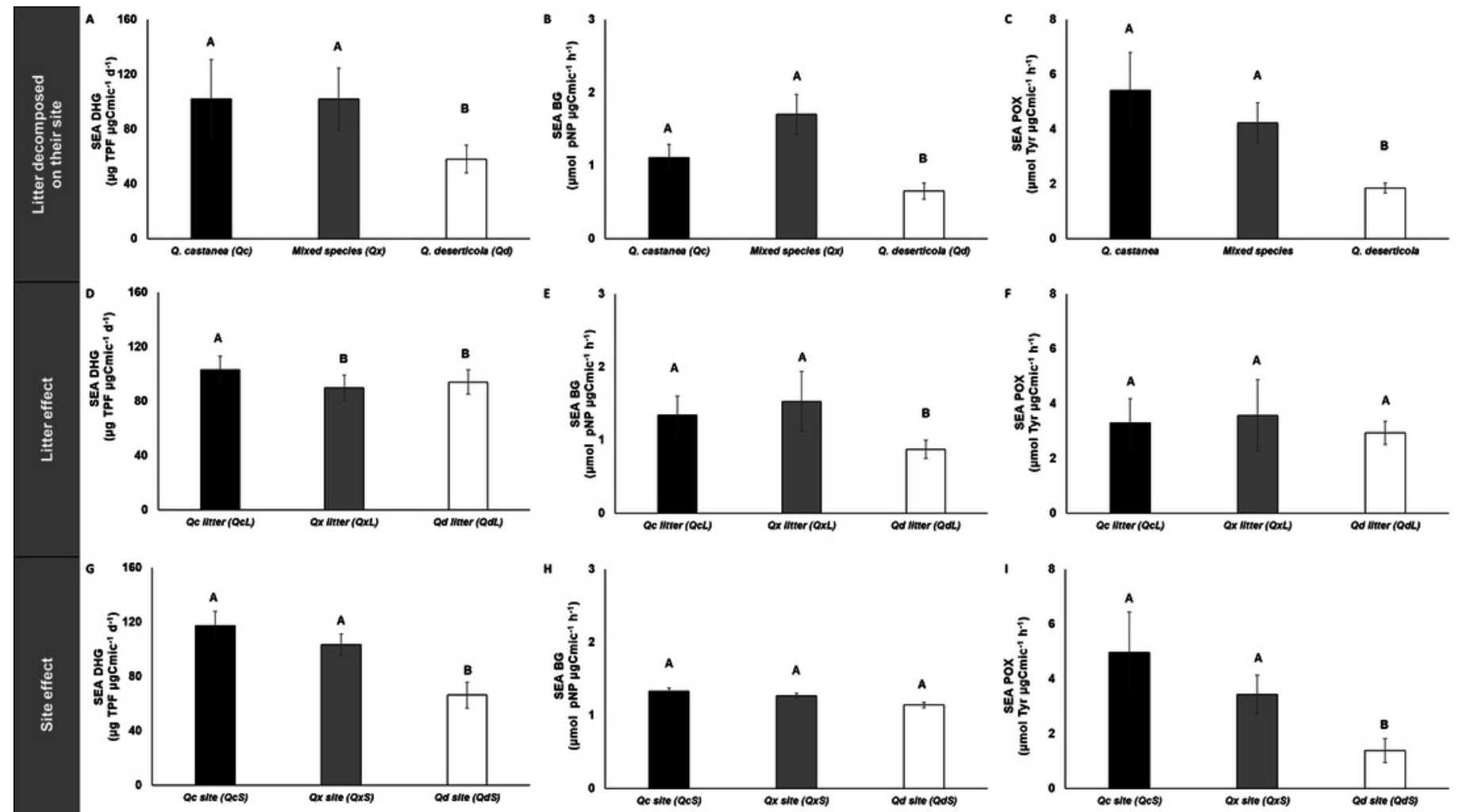


\section{Table $\mathbf{1}$ (on next page)}

Chemical characterization of litterfall and decomposed material in litterbags at 270 days by ${ }^{13} \mathrm{C}$ CPMAS NMR.

HB: hydrophobic compounds; HI: hydrophilic compounds; S: syringyl; G: guaiacyl; H: phidroxypheny. 
1

\begin{tabular}{lcccc}
\hline \multirow{2}{*}{ Chemical shift (ppm) } & \multicolumn{2}{c}{ Q. castanea } & \multicolumn{2}{c}{ Q. deserticola } \\
& Litterfall & 270 days & Litterfall & 270 days \\
\hline Principal regions & & & & \\
- Alkyl C (0-45 ppm) & 11 & 11 & 14 & 18 \\
- O-Alky C (45-110 ppm) & 66 & 64 & 63 & 62 \\
- Aryl C (110-160 ppm) & 18 & 17 & 17 & 15 \\
- Carboxyl C (160-220 ppm) & 6 & 7 & 6 & 6 \\
Ratios and indexes & & & & \\
- Alkyl C:O-Alkyl C & 0.17 & $\mathbf{0 . 1 7}$ & $\mathbf{0 . 2 2}$ & $\mathbf{0 . 2 9}$ \\
- O-Alkyl C:Aromatic C & $\mathbf{3 . 6 6}$ & $\mathbf{3 . 7 4}$ & $\mathbf{e b 3 . 7 1}$ & $\mathbf{4 . 1 3}$ \\
- Hidrophobicity (HB:HI) & $\mathbf{0 . 4 0}$ & $\mathbf{0 . 3 9}$ & $\mathbf{0 . 4 5}$ & $\mathbf{0 . 4 8}$ \\
- Aromaticity & $\mathbf{0 . 2 3}$ & $\mathbf{0 . 2 2}$ & $\mathbf{0 . 2 2}$ & $\mathbf{0 . 1 8}$ \\
- S:G & $\mathbf{1 . 3 5}$ & $\mathbf{1 . 7 5}$ & $\mathbf{1 . 0 0}$ & $\mathbf{1 . 5 0}$ \\
- S:H & $\mathbf{2 . 3 0}$ & $\mathbf{1 . 7 5}$ & $\mathbf{1 . 5 0}$ & $\mathbf{1 . 5 0}$ \\
- G:H & $\mathbf{1 . 1 8}$ & $\mathbf{1 . 0 0}$ & $\mathbf{1 . 4 5}$ & $\mathbf{1 . 0 0}$ \\
\hline
\end{tabular}

2

3 


\section{Table 2 (on next page)}

Thermal characteristics of litterfall and decomposed material inlitterbags at 30 and 270 days analyzed by DSC-TG.

$\mathbf{Q}^{\prime}$ : Energy released per gram of organic matter; $\mathbf{T}_{50}$ : Temperature in which the $50 \%$ of energy release occurs; Percent of energy released in: labile region $\left(\mathbf{Q}_{\mathbf{1}}\right)$, recalcitrant region $\left(\mathbf{Q}_{\mathbf{2}}\right)$ and extra-recalcitrant region $\left(\mathbf{Q}_{\mathbf{3}}\right)$. Temperature in which the peak occurs in: the labile region $\left(\mathbf{T}_{\mathbf{1}}\right)$, recalcitrant region $\left(\mathbf{T}_{\mathbf{2}}\right)$ and extra-recalcitrant region $\left(\mathbf{T}_{3}\right)$. 
1

\begin{tabular}{|c|c|c|c|c|c|c|}
\hline & \multicolumn{3}{|c|}{ Q. castanea } & \multicolumn{3}{|c|}{ Q. deserticola } \\
\hline & Litterfall & 30 days & 270 days & Litterfall & 30 days & 270 days \\
\hline$Q^{\prime}\left(\mathrm{J} \mathrm{gMOS}^{-1}\right)$ & 11122 & 11103 & 11848 & 9085 & 9361 & 11060 \\
\hline $\mathrm{T}_{50}\left({ }^{\circ} \mathrm{C}\right)$ & 396 & 379 & 375 & 400 & 377 & 375 \\
\hline $\begin{array}{l}Q_{1}\left(200-375^{\circ} \mathrm{C}\right) \\
(\%)\end{array}$ & 40.3 & 47.7 & 49.8 & 39.0 & 48.9 & 49.9 \\
\hline $\begin{array}{l}Q_{2}\left(375-475{ }^{\circ} \mathrm{C}\right) \\
(\%)\end{array}$ & 57.0 & 49.7 & 46.1 & 55.9 & 45.5 & 43.6 \\
\hline $\begin{array}{l}Q_{3}\left(475-550{ }^{\circ} \mathrm{C}\right) \\
(\%)\end{array}$ & 2.7 & 2.5 & 4.2 & 5.2 & 5.6 & 6.5 \\
\hline $\mathrm{T}_{1}\left({ }^{\circ} \mathrm{C}\right)$ & 347 & 344 & 343 & 352 & 342 & 350 \\
\hline $\mathrm{T}_{2}\left({ }^{\circ} \mathrm{C}\right)$ & $424 / 449$ & 410 & 425 & 461 & 414 & 432 \\
\hline $\mathrm{T}_{3}\left({ }^{\circ} \mathrm{C}\right)$ & - & - & - & - & 490 & 502 \\
\hline
\end{tabular}

2

3 


\section{Table 3 (on next page)}

Means of thermal parameters obtained through DSC at 30 days of decomposition.

Different capital letters indicate significant differences $(P<0.05)$ according to a one-way ANOVA model. Bold letters are statistically significant. Qc: Quercus castanea litter; Qx: Mixed species litter; Qd: Quercus deserticola litter. The suffixes -L and -S refer to litter and site, respectively. Q': Energy released per gram of organic matter; $\mathbf{T}_{\mathbf{5 0}}$ : Temperature in which the $50 \%$ of energy release occurs; Percent of energy released in: the labile region $\left(\mathbf{Q}_{\mathbf{1}}\right)$, recalcitrant region $\left(\mathbf{Q}_{\mathbf{2}}\right)$ and extra-recalcitrant region $\left(\mathbf{Q}_{\mathbf{3}}\right)$. $\mathbf{F}$ : value of the test statistic; p: significance level. 


\begin{tabular}{lcccc|cccc}
\hline & \multicolumn{5}{c|}{ Litter quality } & \multicolumn{5}{c}{ Site } \\
\cline { 2 - 9 } & QcL & QxL & QdL & $F(p)$ & QcS & QxS & QdS & $F(p)$ \\
\hline $\mathbf{Q}^{\prime}\left(\mathbf{W ~ g}^{-1}\right)$ & 10815 & 10804 & 11083 & $0.53(0.60)$ & 10716 & 11154 & 10832 & $1.35(0.32)$ \\
$\mathbf{T}_{\mathbf{5 0}}\left({ }^{\circ} \mathbf{C}\right)$ & 376 & 375 & 377 & $0.60(0.58)$ & 378 & 375 & 375 & $3.99(0.07)$ \\
$\mathbf{Q}_{\mathbf{1}}(\%)$ & 49.2 & 49.7 & 48.8 & $0.80(0.49)$ & 48.4 & 49.7 & 49.6 & $3.36(0.10)$ \\
$\mathbf{Q}_{\mathbf{2}}(\%)$ & $\mathbf{4 8 . 6 ^ { \mathrm { A } }}$ & $\mathbf{4 6 . 8 ^ { \mathrm { AB } }}$ & $\mathbf{4 5 . 6 ^ { \mathrm { B } }}$ & $\mathbf{1 7 . 8}(<0.01)$ & 47.2 & 46.8 & 46.9 & $0.04(0.95)$ \\
$\mathbf{Q}_{\mathbf{3}}(\%)$ & $\mathbf{2 . 2 ^ { \mathrm { B } }}$ & $\mathbf{3 . 4 ^ { \mathrm { B } }}$ & $\mathbf{5 . 6 ^ { \mathrm { A } }}$ & $\mathbf{2 0 . 4}(<0.01)$ & 4.3 & 3.5 & 3.4 & $0.25(0.78)$ \\
\hline
\end{tabular}




\section{Table 4 (on next page)}

Means of the concentration of total and dissolved $\mathrm{C}, \mathrm{N}$ and $\mathrm{P}$ in litterfall anddecomposed litter at 30 and 270 days for Q.castanea, mixture of species and Q.deserticola at their site of origin.

Different uppercase letters indicate significant differences $(p<0.05)$ between litter types within the same date. Different lowercase letters indicate significant differences $(p<0.05)$ between dates within the same litter type according to a repeated measures ANOVA (RMANOVA). 


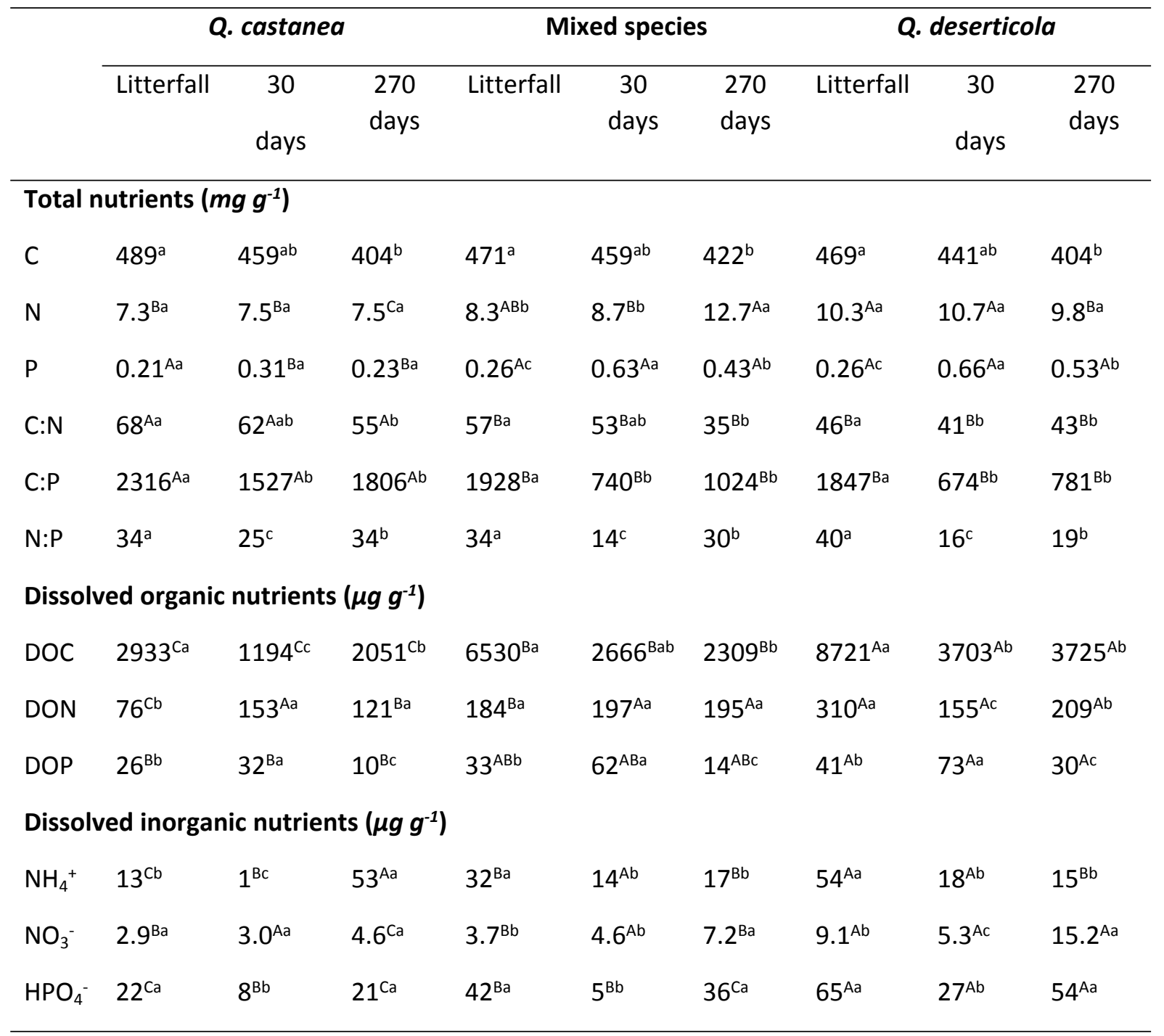

1 


\section{Table 5 (on next page)}

Multiple regression models at 30 days of decomposition between litter remnant mass and litter chemical quality and microbial metabolism variables.

Bold letters refer to significant variables according to a multiple regression model. 


\begin{tabular}{|c|c|c|c|}
\hline Factors & Included variables & $\begin{array}{c}\text { Significant variables } \\
\text { (ß) }\end{array}$ & $\begin{array}{c}\text { Multiple } R^{2} \\
\text { (p) }\end{array}$ \\
\hline \multirow{8}{*}{ Chemical quality } & C:N ratio & 0.29 & \multirow{8}{*}{$0.78(<0.001)$} \\
\hline & $\mathrm{C}: \mathrm{P}$ ratio & $N S$ & \\
\hline & DOC & $N S$ & \\
\hline & DON & -0.56 & \\
\hline & DOP & -0.23 & \\
\hline & $\mathbf{N H}_{4}^{+}$ & -0.24 & \\
\hline & $\mathrm{NO}_{3}^{-}$ & $N S$ & \\
\hline & $\mathrm{PO}_{4}^{-}$ & $N S$ & \\
\hline \multirow{6}{*}{ Microbial metabolism } & SEA BG & $N S$ & \multirow{6}{*}{$0.38(0.033)$} \\
\hline & SEA CBH & $N S$ & \\
\hline & SEA POX & -0.45 & \\
\hline & SEA NAG & $N S$ & \\
\hline & SEA PHO & $N S$ & \\
\hline & SEA DHG & 0.41 & \\
\hline
\end{tabular}

1 